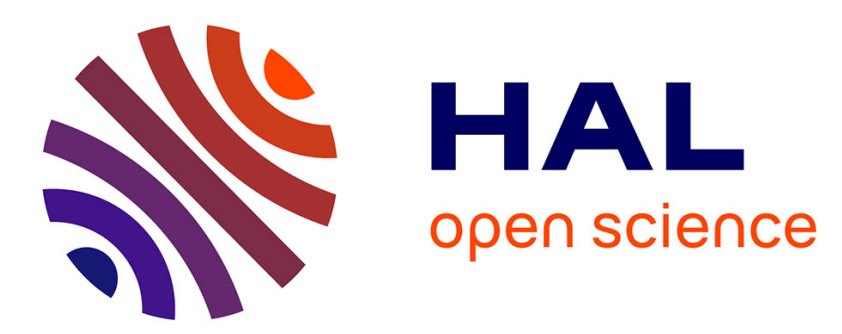

\title{
Ligand-Controlled Regiodivergent Palladium-Catalyzed Hydrogermylation of Ynamides
}

Vincent Debrauwer, Aneta Turlik, Lénaic Rummler, Alessandro Prescimone, Nicolas Blanchard, K. Houk, Vincent Bizet

\section{- To cite this version:}

Vincent Debrauwer, Aneta Turlik, Lénaic Rummler, Alessandro Prescimone, Nicolas Blanchard, et al.. Ligand-Controlled Regiodivergent Palladium-Catalyzed Hydrogermylation of Ynamides. Journal of the American Chemical Society, 2020, 142 (25), pp.11153-11164. 10.1021/jacs.0c03556 . hal02868667

\section{HAL Id: hal-02868667 \\ https://hal.science/hal-02868667}

Submitted on 6 Nov 2020

HAL is a multi-disciplinary open access archive for the deposit and dissemination of scientific research documents, whether they are published or not. The documents may come from teaching and research institutions in France or abroad, or from public or private research centers.
L'archive ouverte pluridisciplinaire HAL, est destinée au dépôt et à la diffusion de documents scientifiques de niveau recherche, publiés ou non, émanant des établissements d'enseignement et de recherche français ou étrangers, des laboratoires publics ou privés. 


\title{
Ligand-Controlled Regiodivergent Palladium-Catalyzed Hy- drogermylation of Ynamides
}

\author{
Vincent Debrauwer, ${ }^{\dagger \#}$ Aneta Turlik, ${ }^{\ddagger \#}$ Lénaic Rummler, ${ }^{\dagger}$ Alessandro Prescimone, ${ }^{\dagger}$ Nicolas Blan- \\ chard,,$^{\dagger} *$ K. N. Houk, ${ }^{\ddagger}, *$ Vincent Bizet ${ }^{\dagger}, *$ \\ $\dagger$ Université de Haute- Alsace, Université de Strasbourg, CNRS, LIMA, UMR 7042, 68000 Mulhouse (France) \\ +ै University of Basel, Chemistry Department, Mattenstrasse 24a, 4058 Basel (Switzerland) \\ † Department of Chemistry and Biochemistry, University of California, Los Angeles, California 90095 (United States)
}

\begin{abstract}
Ynamides are fascinating small molecules with complementary reactivities under radical, ionic and metal-catalyzed conditions. We report herein synthetic and DFT investigations of palladium-catalyzed ligand-controlled regiodivergent hydrometallation reactions of ynamides. Germylated and stannylated enamides are obtained with excellent $\alpha, E$ - or $\beta, E$-selectivities and a broad functional group tolerance. Such a regiodivergent palladium-catalyzed process is unique in ynamide chemistry and allows for the elaboration of metallated-enamides that are useful building blocks for cross-coupling reactions or heterocyclic chemistry. DFT calculations fully support the experimental data and demonstrate the crucial roles of the trans-geometry of the [H-Pd(L)-Ge] complex, as well as of the steric requirements of the phosphine ligand. In addition, the prevalence of a hydro-palladation pathway over a metal-palladation of the $\pi$ system of the ynamide was demonstrated.
\end{abstract}

\section{Introduction}

Vinyltin $^{1}$ and vinylsilane ${ }^{2}$ compounds exhibit intrinsic reactivities in electrophilic substitution reactions and metal-mediated cross-coupling reactions, which have been central to the elaboration of complex molecular architectures. Although in the same column of the periodic table, organogermanium compounds ${ }^{3}$ have been less studied than organotin and organosilicon derivatives in spite of their interesting chemical properties, their reactivity profiles and their absence of toxicity. ${ }^{4-6}$ Replacement of carbon by silicon or germanium in a given small molecule leads to a "silicon or germanium switch" that confers an increased lipophilicity that can improve biological activities of hydrophobic pharmacophores as shown in the case of a retinoic acid receptor ligand ${ }^{7}$ or an estrogen receptor ligand. ${ }^{8}$ This beneficial increase in hydrophobicity was mainly attributed to the difference in covalent radius of the central atom.

Carbon-germanium bonds are usually formed via: radical additions of germyl radicals to alkenes or alkynes, ${ }^{9}$ germylmetalation of alkynes or enones, ${ }^{10}$ ruthenium- or iridium-catalyzed germylative coupling of terminal alkynes, ${ }^{11}$ palladium-catalyzed germylation of aryl (pseudo) halides, ${ }^{12}$ Lewis acid-catalyzed hydrogermylation, ${ }^{13}$ visible-light-initiated manganese-catalyzed hydrogermylation, ${ }^{14}$ or more generally using Fe- ${ }^{15} \mathrm{Rh}-,{ }^{16}$ $\mathrm{Ru}-{ }^{17} \mathrm{Pd}^{18}$ or $\mathrm{Pt}^{19}{ }^{19}$ catalyzed hydrogermylation reactions of alkenes or alkynes. ${ }^{20}$ Although hydrogermylation reactions of alkynes have been studied since the late
$1950 \mathrm{~s},{ }^{21}$ control over regio- and stereoselectivity remains challenging in most cases, thus limiting access to regio- and stereodefined vinylgermanes. ${ }^{9-22} E / Z$ Stereoselectivity has been mainly controlled by the nature of the metal and/or the reaction conditions. Regioselectivity has been reported to be moderate when not biased by specific reaction conditions or by inherent functionalities that play the role of directing groups. Important breakthroughs by the Fürstner group recently provided two efficient ruthenium-based catalytic systems for the regio-, chemo- and stereoselective trans-hydrogermylation of propargylic alcohols. A protic functional group proved to be essential for coordination with the metal, and depending on the ruthenium catalyst used, $\left[\mathrm{Cp} * \mathrm{Ru}(\mathrm{MeCN})_{3}\right] \mathrm{PF}_{6}$ or $(\mathrm{Cp} * \mathrm{RuCl})_{4}$, the regioselectivity of the hydrogermylation could be inverted (proxi$\mathrm{mal} /$ distal $=24: 76$ to $86: 14) .{ }^{17 \mathrm{~b}, 23}$

Nitrogen-substituted alkynes are versatile building blocks whose reactivities have been studied over the past two decades. ${ }^{24,25}$ If ynamides could be hydrometallated with complete control over regio- and stereoselectivity, stereodefined metallated-enamides would be accessible and could be further functionalized using typical enamide or vinylmetal reactions. $\beta$-Regioselectivity has been observed in radical silylzincation, ${ }^{26 a}$ hydrosilylation reactions using Lewis acid-catalyzed, ${ }^{26 \mathrm{~b}} \mathrm{Rh}$ catalysis, ${ }^{26 \mathrm{c}}$ and $\mathrm{Cu}$-catalysis, ${ }^{26 \mathrm{e}}$ silylzincation using $\left(\mathrm{Me}_{2} \mathrm{PhSi}\right)_{2} \mathrm{Zn}$ or $\left[\left(\mathrm{Me}_{3} \mathrm{Si}\right)_{3}\right]_{2} \mathrm{Zn},{ }^{26 \mathrm{~d}}$ as well as in hydrogermylation using radical germylzincation conditions (Scheme 1, a). ${ }^{27}$ 
Scheme 1. State of the art for ynamide hydrometallation (a,b), current challenge (c) and reaction design for ligandcontrolled palladium-catalyzed regiodivergent hydrogermylation of ynamides (d)

a) Hydrosilylation and radical germylzincation of ynamides are $\beta$-selective
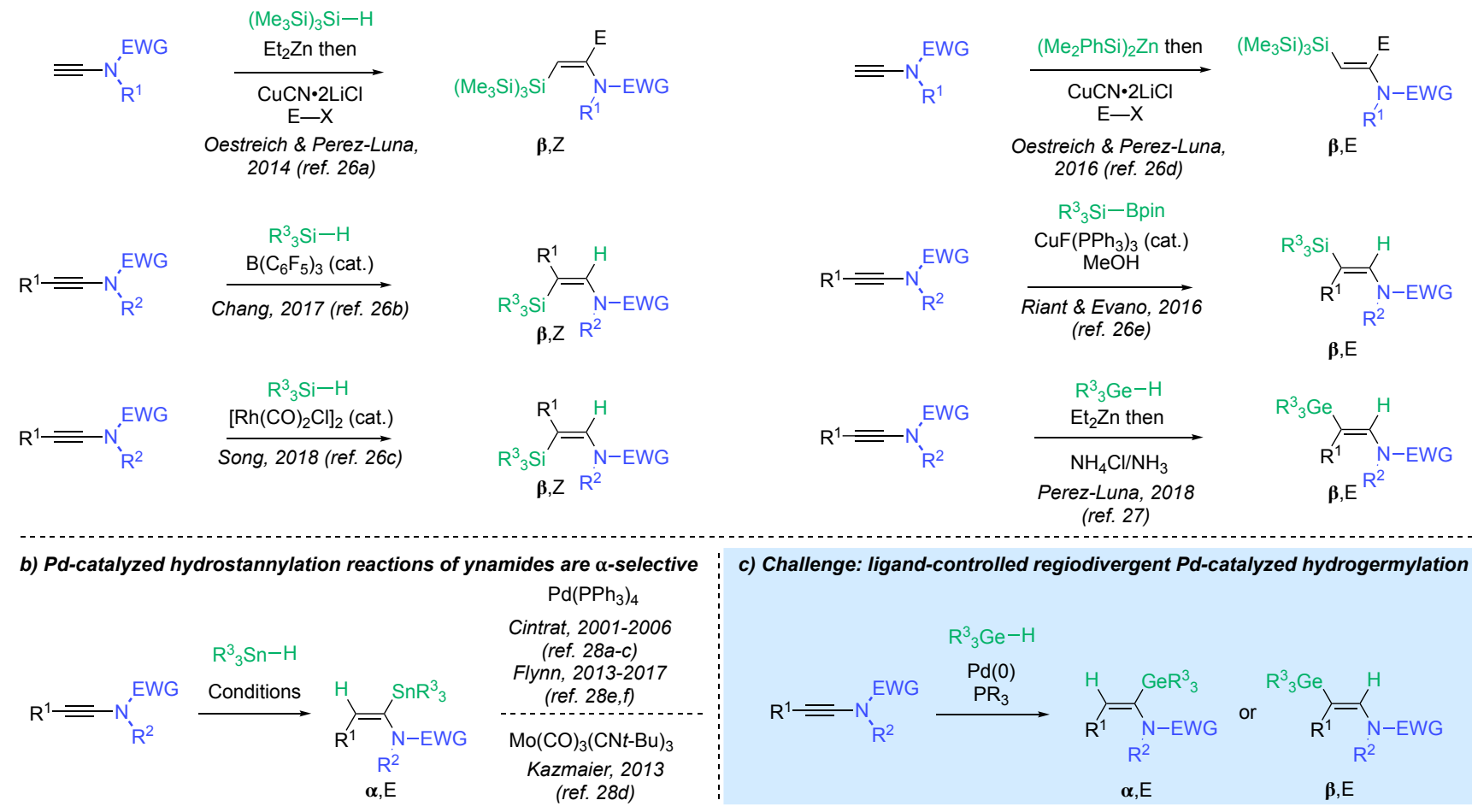

d) Reaction design based on ligand sterics
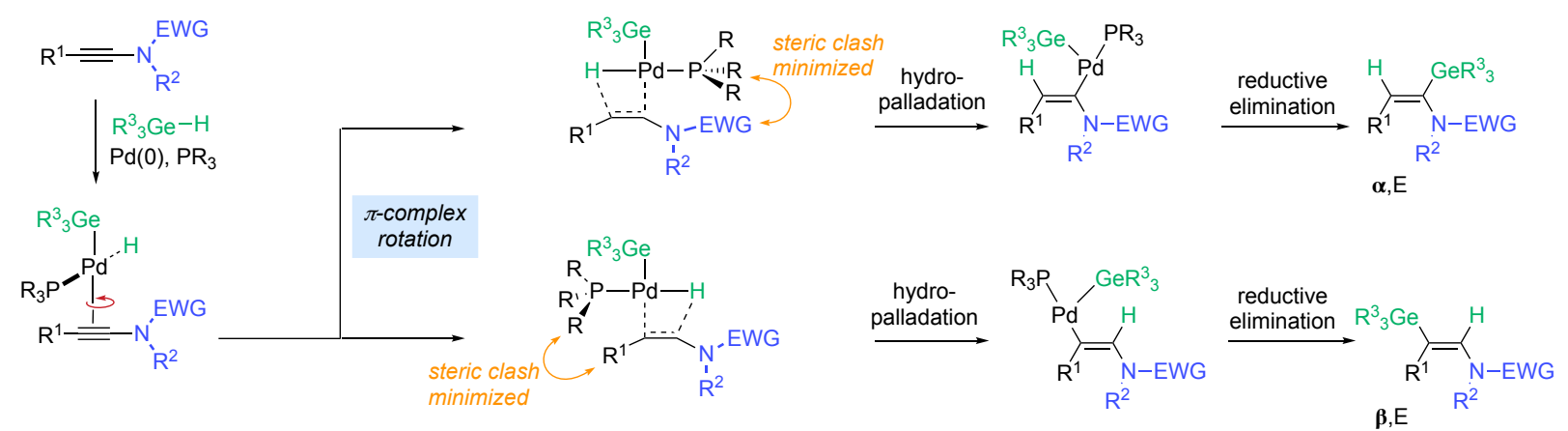

On the other hand, $\alpha$-regioselectivities were obtained in the palladium- ${ }^{28 \mathrm{a}-\mathrm{c}, \mathrm{e}, \mathrm{f}}$ or molybdenum-catalyzed ${ }^{28 \mathrm{~d}}$ hydrostannylation of ynamides (Scheme 1, b), except in the case of camphorsultam-derived ynamides for which a slight preference for $\beta$-regioselectivity was reported. ${ }^{28, \mathrm{f}}$

A current major challenge in ynamide chemistry is the flexible control of regioselectivity during the addition of a functional group across the $\pi$ system, which is intrinsically biased due to the strong polarization of the alkyne leading to the formation of a carbon-functional group bond preferentially in the $\alpha$ position. ${ }^{29}$ Different strategies have been studied to redirect the formation of such bonds to the $\beta$ position of ynamides based on ring-strain, chelation to the nitrogen electron-withdrawing substitu-

ent of the alkyne, base-mediated addition and radicalinitiated reactions. ${ }^{29,30}$ We report herein a complementary strategy for such control in ynamide chemistry by showing that the regioselectivity of palladium-catalyzed hydrogermylation reactions of ynamides can be ligandcontrolled (Scheme 1, c). Only rare precedents of ligandcontrolled regiodivergency are known for other types of metal-catalyzed reactions of ynamides, such as the rhodium-catalyzed hydroformylation ${ }^{30 a}$ or the goldcatalyzed synthesis of indoles. ${ }^{30 b}$ Depending on the steric requirements of the phosphine ligand, excellent $\alpha$ - or $\beta$ regioselectivities and perfect stereoselectivities $(E / Z>$ 99:1) are obtained in this ligand-controlled regiodivergent hydrogermylation (Scheme 1, d). DFT investigations of this reaction of ynamides shed light on the observed inversion of regioselectivity and point to the 
crucial interplay between the steric requirements of the ligands and the geometry of the [H-Pd-GeR 3 complex in the competing transition states.

Table 1. Screening of reaction conditions

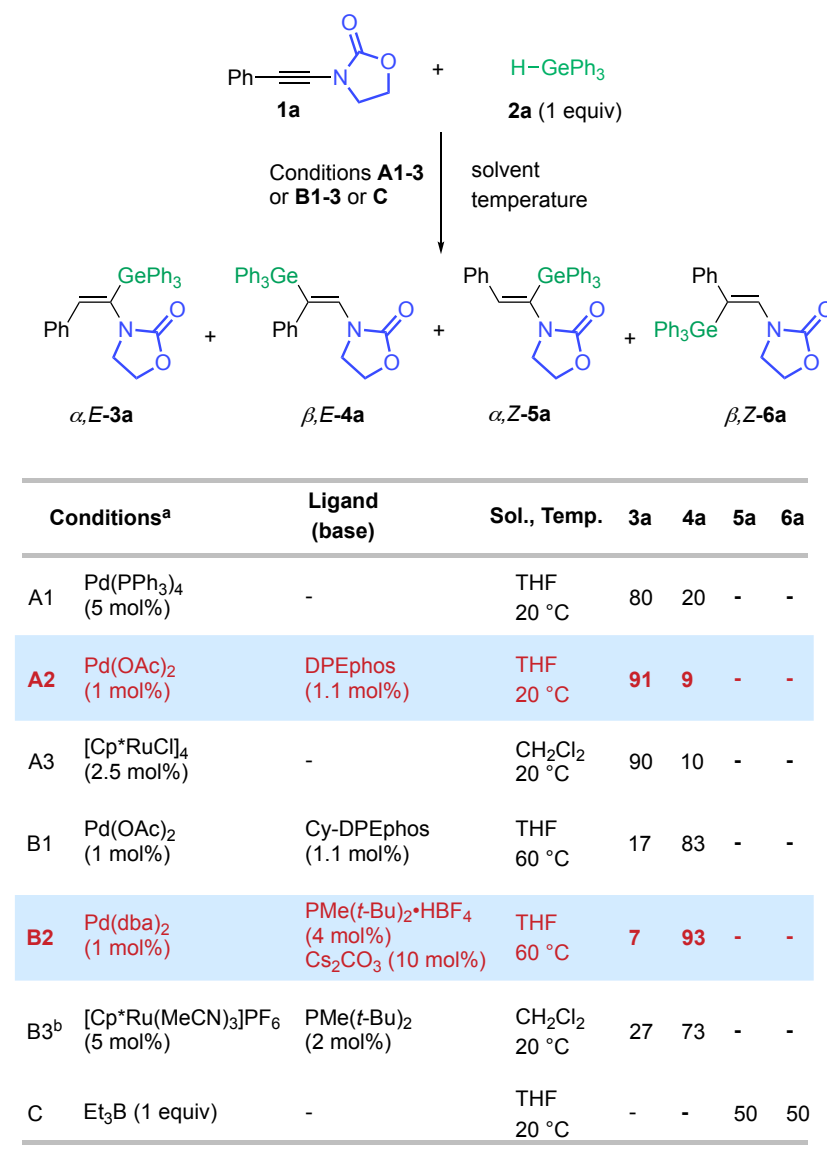

${ }^{a}$ Reaction conditions: Ynamide 1a (1 equiv.), $\mathrm{HGePh}_{3}$ 2a (1 equiv.). Ratio of products were measured by ${ }^{1} \mathrm{H}$ NMR ${ }^{b}$ Incomplete conversion after $16 \mathrm{~h}$.

\section{Results and discussion}

Screening of reaction conditions. Studies of the regiodivergency in palladium-catalyzed hydrogermylation reactions of ynamides were initiated with model compound 1. Using $\mathrm{Pd}\left(\mathrm{PPh}_{3}\right)_{4}$ as a standard $\mathrm{Pd}(0)$ complex (conditions A1), stereoselective cis-hydrogermylation takes place yielding exclusively $E$-enamides $\mathbf{3 a}$ and $\mathbf{4 a}$ in a 80:20 ratio.

Ligand screening showed that it was possible to improve this ratio up to 91:9 in favor of $\mathbf{3 a}$ using DPEphos as ligand (conditions A2). Gratifyingly, switching from DPEphos to Cy-DPEPhos completely reversed the regioselectivity in favor of the $\beta, E$-isomer 4a (conditions B1). Further ligand screening led us to improve the $\beta$ selectivity up to 7:93 in favor of $\mathbf{4 a}$ using $\mathrm{P}(t-\mathrm{Bu})_{2} \mathrm{Me}$, an electron-rich and bulky monophosphine ligand (conditions B2).

For comparison, Ru-catalyzed stereoselective transhydrometallation conditions reported by the Fürstner group ${ }^{17 b, 23}$ were evaluated. These conditions were previously shown to produce trans-addition products in the reactions of propargylic alcohols. However, in the case of ynamide substrate 1a, $\boldsymbol{Z}$-5a and $\boldsymbol{Z}$-6a (arising from a trans-hydrogermylation) were not observed under conditions $\mathbf{A 3}\left([\mathrm{Cp} * \mathrm{RuCl}]_{4}\right.$, dichloromethane, $\left.20{ }^{\circ} \mathrm{C}\right)$ nor under conditions $\mathbf{B 3}\left(\left[\mathrm{Cp} * \mathrm{Ru}(\mathrm{MeCN})_{3}\right] \mathrm{PF}_{6}\right.$, dichloromethane, $20{ }^{\circ} \mathrm{C}$ ). Only $\boldsymbol{E}$-3a and $\boldsymbol{E}-\mathbf{4 a}$ were obtained with variable $\alpha / \beta$ ratios (A3: 90:10, B3: 27:73). A similar trend was observed with triethylgermane, but with slightly lower regioselectivity. Although the trend in $\alpha: \beta$ selectivity was comparable to that reported by Fürstner, the reversal of $E / Z$ stereoselectivity indicates that the hydrogermylation proceeds through a different mechanism for ynamides. Finally, we found that enamides $\boldsymbol{Z}$ 5a and $\boldsymbol{Z}$-6a could be obtained in a 50:50 ratio using radical reaction conditions with triethylborane as radical initiator $(\mathbf{C}) .^{9 \mathrm{a}, 31}$ Structures of all four stereoisomers were clearly identified using extensive NMR characterization and X-ray diffraction studies (Figure 1). ${ }^{31,32}$

These studies indicate that ligand sterics play indeed a crucial role during these Pd-catalyzed hydrogermylation of ynamides, as was hypothesized at the outset of these investigations. Indeed, a relatively small monophosphine ligated to palladium(0) (as in conditions A1 with triphenylphosphine or in conditions $\mathbf{A 2}$ with the $\mathrm{PP}(\mathrm{O})^{33}$ ligand arising from the mono-oxidation of DPEphos) leads to an $\alpha$-selective reaction ( $\alpha / \beta$ up to 91:9). On the other hand, a bulky and electron-rich monophospine ligand (as in conditions $\mathbf{B} 1$ with a bulky $\mathrm{PP}(\mathrm{O})$ ligand or in conditions $\mathbf{B 2}$ with $\left.\mathrm{P}(t-\mathrm{Bu})_{2} \mathrm{Me}\right)$ allows for a $\beta$ selective reaction, up to $\alpha / \beta=7: 93$.

Scope and limitations. Having established reaction conditions allowing for a regioselectivity switch, we turned our attention to the scope and limitations of the palladium-catalyzed hydrogermylation of ynamides (Schemes 2 and 3). Three sets of conditions were tested, one $\alpha$-selective (Conditions A2) and two $\beta$-selective (Conditions B1 and B2), on 25 different ynamides.

The nature of the electron withdrawing group connected to the nitrogen atom of the ynamides was first evaluated (Scheme 2), with motifs such as oxazolidinones (1a, 1f), azetidinone (1b), 2-pyrrolidinone (1c), methyl carbamates (1d, 1 m), ${ }^{34} 3$-carbomethoxyindole (1d), ${ }^{35}$ 1,1-dioxo-isothiazolidine (1g) and sulfonamides $(\mathbf{1 h}-\mathbf{l})$. It was rapidly observed that the nature of this substituent could enhance or reduce the selectivity imposed by the ligands under conditions A2, B1 and B2. In all cases, $E / Z$ selectivities were always $>99: 1$. 
2-Oxazolidinone (1a) confers a good balance to ynamides, and high yields and regioselectivities were observed in both A2 ( $\alpha$-selective, 91:9) or B2 ( $\beta$-selective, 7:93) conditions. Increased steric demand on the oxazolidinone motif impacts only $\alpha$-selectivity in conditions $\mathbf{A 2}$ as can be seen for ynamides $1 \mathbf{f}(\alpha / \beta=77: 23, \mathbf{3 f} / \mathbf{4 f})$.

Lactams lead to good $\alpha$-selectivity under conditions A2 whereas a moderate $\beta$-selectivity was obtained under conditions B1 or B2. Indeed, with azetidinone, formation of $\mathbf{3 b}$ is strongly favored in $\mathbf{A 2}$ conditions $(\alpha / \beta=$ $96: 4, \mathbf{3 b} \mathbf{b} \mathbf{4 b})$. In contrast, the $\beta$-selectivity is only modest under conditions $\mathbf{B} 1$ and $\mathbf{B 2}$, with at best $\alpha / \beta=32: 68$ $(\mathbf{3 b} / \mathbf{4 b})$. Increase of the ring size to 2-pyrrolidinone slightly decreases $\alpha$-selectivity in conditions A2 (3c) along with an improved $\beta$-selectivity in conditions $\mathbf{B} 1$ or B2 (4c).

With the dimethyl carbamate 1d, which can be considered as the open form of oxazolidinone 1a, the $\alpha$ selectivity drops to $62: 38(\mathbf{3 d} / \mathbf{4 d})$ while the $\beta$-selectivity increases up to $4: 96(\mathbf{3 d} / \mathbf{4 d})$.

3-Carbomethoxyindole-derived ynamide 1e, a vinyloguous carbamate, leads to an $\alpha$-selectivity of $86: 14$ (3e/4e) in conditions A2, while $\beta$-selective conditions are not effective $(\alpha / \beta=53: 47, \mathbf{3 e} / \mathbf{4 e})$ under conditions B2.

Cyclic and acyclic sulfonamides were next evaluated. 1,1-Dioxo-isothiazolidine-derived ynamide $1 \mathrm{~g}$ proved to be a good substrate with high $\alpha$ - or $\beta$-regioselectivities under the appropriate conditions: $\alpha / \beta=84: 16(\mathbf{3 g} / \mathbf{4 g})$ under conditions $\mathbf{A 2}$, that switches to $\alpha / \beta=0: 100$ under conditions B2.

On the other hand, the five non-cyclic analogs $\mathbf{1 h}-\mathbf{I}$ lead to a $\beta$-selective hydrogermylation, under all reaction conditions (A2, B1 or B2). The $\alpha, E$-isomers $\mathbf{3 h}$ and 3i could still be observed as minor products $(\alpha / \beta=$ $25: 75$ and $17: 83$, respectively) when the nitrogen atom is substituted by a methyl group. With increased steric bulk of this substituent, as with $N$-cyclopropyl $\mathbf{1} \mathbf{j}, N$-benzyl $\mathbf{1 k}$ or the highly demanding $\mathbf{1}$, only the $\beta, E$-isomers $4 \mathbf{j}-\mathbf{I}$ are detected $(\alpha / \beta=0: 100)$.

Finally, the reactivity of ynamide $1 \mathbf{m}$ possessing two $\pi$-systems was evaluated. Only the hydrogermylation of the alkynyl motif was observed at a higher temperature $\left(60{ }^{\circ} \mathrm{C}\right)$. Three different products were obtained: the expected $\alpha$ - and $\beta$-isomers (3m and $\mathbf{4 m}$ ) and a third product, $7 \mathbf{m}$, arising from the $\alpha$-selective mechanism (see Scheme 4 and discussion below).
Scheme 2. Variation of the nitrogen motif ${ }^{\mathrm{a}}$
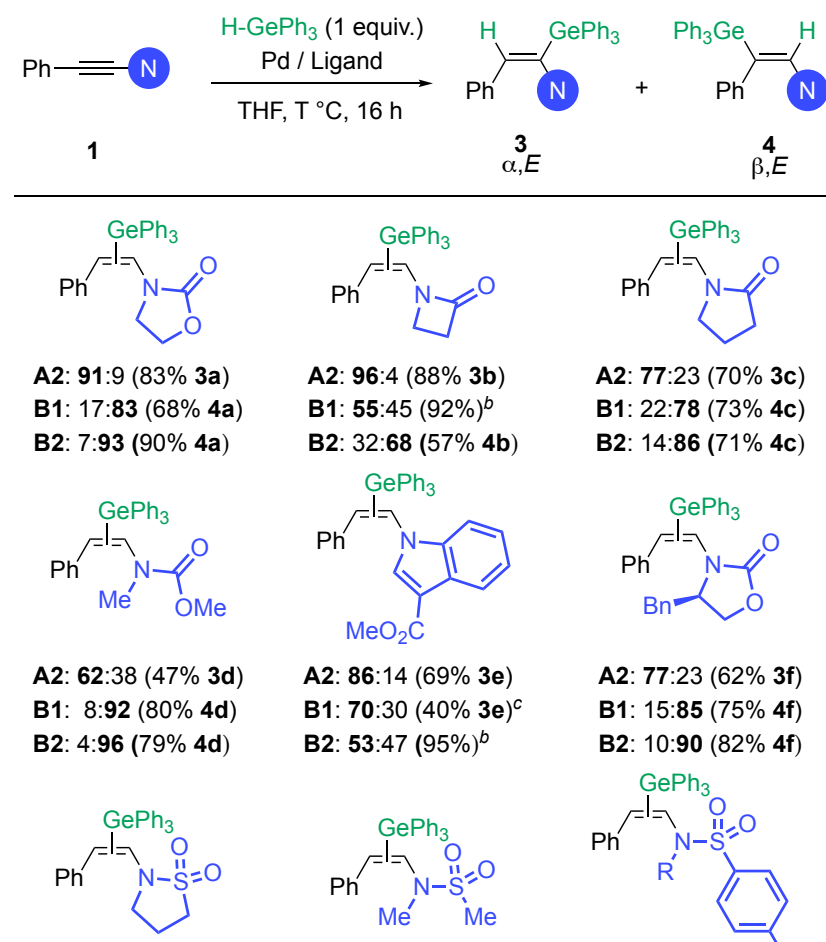

A2: $86: 14(69 \% 3 e)$ B1: $70: 30(40 \% 3 e)^{c}$ B2: $53: 47(95 \%)^{b}$

A2: $77: 23(62 \% 3 f)$ B1: $15: 85$ (75\% 4f) B2: $10: 90$ ( $82 \%$ 4f)

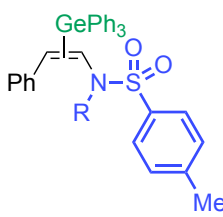

$\mathrm{R}=\mathrm{Me}$

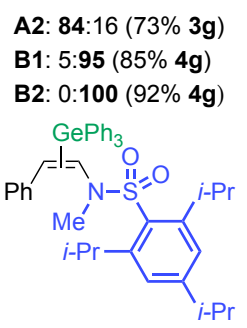

A2: $25: 75(86 \%)^{b}$

B1: 0:100 (94\% 4h)

B2: 0:100 (86\% 4h)

A2: $17: 83(60 \% 4 i)^{c}$ B1: 0:100 (91\% 4i) B2: 0:100 (93\% 4i)

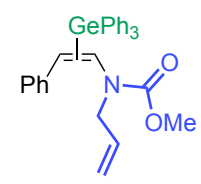

$\mathrm{R}=$ cyclopropyl A2: 0:100 $(60 \% 4 \mathbf{j})^{c}$ B1: 0:100 $(63 \% 4 \mathbf{j})^{c}$ B2: 0:100 (83\% 4j)

A2: $0: 100(65 \% 4 I)^{C}$ B1: 0:100 (88\% 4I) B2: 0:100 $(86 \% 4 I)^{c}$
$\mathrm{R}=\mathrm{Bn}$

A2: 0:100 $(78 \% 4 k)$ B1: 0:100 (85\% 4k) B2: 0:100 (88\% 4k)

${ }^{a}{ }^{1} \mathrm{H}$ NMR $\alpha: \beta$ ratio (3:4), isolated yields of the major isomer in brackets. ${ }^{b}$ Combined yield. ${ }^{c}$ Reaction incomplete after $24 \mathrm{~h}$, conversion indicated in brackets. ${ }^{d}$ Reaction performed at $60{ }^{\circ} \mathrm{C} .{ }^{e}$ Formation of another product $\mathbf{7 m}$ was observed (A2: $57 \%$, B1: 15\%, B2: 30\%), see Scheme 4 for details.

Under conditions $\mathbf{A 2}$, an $\alpha$-selectivity comparable to the oxazolidinone case (1a) was observed $(\alpha / \beta=90: 10$, $\mathbf{3} \mathbf{m}+\mathbf{7 m} / \mathbf{4 m})$. The highest degree of $\beta$-selectivity was obtained with conditions B1, with $\alpha / \beta=25: 75$ $(\mathbf{3 m}+\mathbf{7 m} / \mathbf{4 m})$.

The scope with regards to the substituent of the $\pi$ system of the ynamides was then evaluated, keeping constant the nitrogen substituent as the oxazolidinone (Scheme 3). Once again, an inversion of $\alpha$ - to $\beta$ selective palladium-catalyzed hydrogermylation was 
observed with all carbon-based substituents, when switching from conditions A to conditions $\mathbf{B}$.

\section{Scheme 3. Variation of the terminal position and metal ${ }^{\mathrm{a}}$}
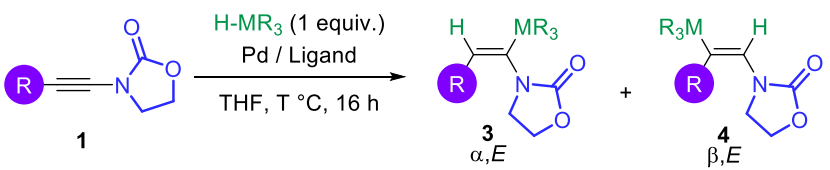

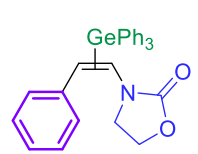

A2: $91: 9(83 \% 3 a)$ B2: $7: 93(90 \% 4 a)$

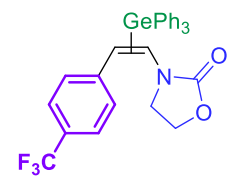

A2: $69: 31(55 \% 3 r)$ B2: $3: 97(45 \% 4 r)^{e}$

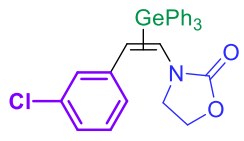

A2: $75: 25(43 \% 3 \mathrm{t})$ B2: $5: 95(85 \% 4 t)$

A2: $\mathbf{9 0 : 1 0}(51 \% \mathbf{3 w})^{b}$ B2: $42: 58(10 \% 4 w)^{b}$

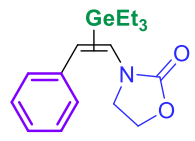

A2: $70: 30(42 \% \text { 3aa })^{d}$ B2: $20: 80(32 \% 4 a a)^{e}$

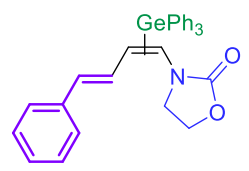

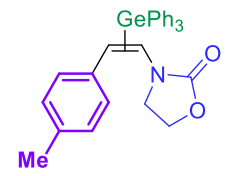

A2: $96: 4(86 \% 3 n)$ B2: $14: 84(65 \% 4 n)$

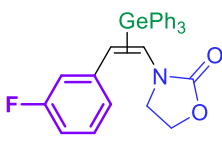

A2: $80: 20(60 \% 3 \mathrm{~s})$ B2: $4: 96(83 \% 4 s)$

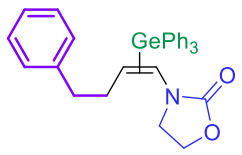

A2: $74: 26(69 \% 3 u)$ B2: $16: 84(64 \% 4 u)$ A1: $85: 15(57 \% 3 u)$

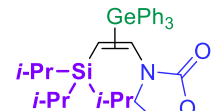

A2: $100: 0(27 \% 3 x)^{c}$ B2: $100: 0(26 \% 3 \mathbf{x})^{c}$ A1: $92: 8(90 \% 3 \mathbf{x})$

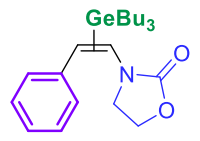

A2: $72: 28(56 \% 3 \mathbf{a b})^{d}$ B2: $23: 77(32 \% 4 a b)^{e}$

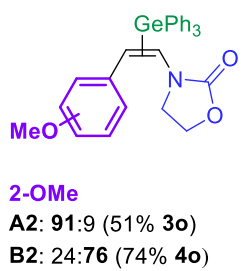

3-OMe

A2: $96: 4(84 \% 3 \mathbf{p})$

B2: $8: 92(75 \% 4 p)$

4-OMe

A2: $75: 25$ (54\% 3q)

B2: $10: 90(69 \% 4 q)$

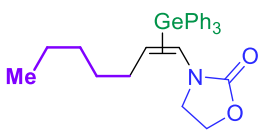

A2: $69: 31(61 \% 3 v)$ B2: $26: 74(42 \% 4 v)$ A1: $99: 1(67 \% 3 v)$

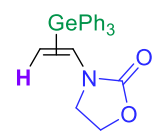

A2: $45: 55(89 \%$ 3-4y) B2: 0:100 (93\% 4y)

A1: $95: 5(72 \%$ 3ac $)$

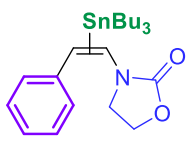
B2: $5: 95(82 \% 4$ ac $)$

a 1 H NMR $\alpha: \beta$ ratio (3:4), isolated yields of the major isomer in brackets. ${ }^{\mathrm{b}}$ Some degradation was observed. ${ }^{\mathrm{c}}$ Reaction incomplete after $24 \mathrm{~h}$, conversion indicated in brackets. ${ }^{\mathrm{d}}$ Reaction performed at $60{ }^{\circ} \mathrm{C}$. ${ }^{\mathrm{e}}$ Reaction performed at $90{ }^{\circ} \mathrm{C}$.

Aryl substituents were first considered. Compared to ynamide 1a (Scheme 3), an electron-donating group such as 4-Me (1n) or OMe (10-q) on the aromatic ring favors the $\alpha$-selectivity ( $\alpha / \beta$ up to $96: 4,3 \mathbf{3} / \mathbf{4 n}$ ) in condition A2, while the $\beta$-selectivity remains high in conditions $\mathbf{B} 2(\alpha / \beta$ up to 8:92). In contrast, an electronwithdrawing substituent such as $4-\mathrm{CF}_{3}(\mathbf{1 r}), 3-\mathrm{F}$ (1s) or 3 - $\mathrm{Cl}$ (1t) greatly improves the $\beta$-selectivity in conditions
B2 $(\alpha / \beta$ up to $3: 97,3 \mathbf{3} / \mathbf{4 r})$. A slight erosion of $\alpha$ selectivity was noticed for this class of substrates $(\alpha / \beta$ up to $80: 20, \mathbf{3 s} / \mathbf{4 s}$ ). It should be noted that a 4bromophenyl substituent was not tolerated in this palladium-catalyzed reaction as competitive carbon-bromine bond reduction was observed, in a more complex reaction mixture. Alkyl substituents on the ynamides were next evaluated. Excellent $\alpha$-selectivities were observed under conditions $\mathbf{A 1}(\alpha / \beta$ up to $99: 1, \mathbf{3 v} / \mathbf{4 v})$, and a good level of $\beta$-selectivities were obtained under conditions B2 $(\alpha / \beta$ up to $16: 84,3 \mathbf{u} / \mathbf{4 u})$. Vinyl-substituted ynamide $1 \mathbf{w}$ was also studied, which raises the question of the chemoselectivity of the hydrogermylation. Only cisaddition of triphenylgermanium hydride across the alkynyl $\pi$-system was observed, leading to enamides $\mathbf{3 w}$ or $4 \mathbf{w}$.

Tri-(isopropyl)silyl-substituted ynamide $\mathbf{1 x}$ is the only heterosubstituted ynamide that was screened during these studies. The bulkiness of this substituent leads to an $\alpha$-selective hydrogermylation under conditions $\mathbf{A 2}$ and also B2, with limited conversions (27 and 26\% respectively). Conditions A1, implying a less bulky phosphine, were much more efficient and delivered the $\alpha, E$ isomer $3 \mathbf{x}$ in $90 \%$ isolated yield and an $\alpha / \beta$ ratio of $92: 8$. In contrast, the absence of a substituent at the $\beta$-position (1y) makes this reaction fully $\beta$-regioselective in conditions B2. The $\beta, E$-isomer $\mathbf{4 y}$ was obtained in $93 \%$ isolated yield and an $\alpha / \beta$ ratio of $0: 100$.

In conditions A2, the hydrogermylation was essentially non-regioselective and an $\alpha / \beta$ ratio of 45:55 (3y/4y) was obtained. At first glance, this result might seem disappointing; however it should be noted that palladium-catalyzed hydrogermylation reactions of terminal alkynes almost exclusively lead to the $\beta$-regioselectivity, almost exclusively. ${ }^{16 \mathrm{c}, 18 \mathrm{a}, 18 \mathrm{~d}}$ In this regard, obtaining $45 \%$ of the $\alpha$-isomer in conditions $\mathbf{A 2}\left(\mathrm{Pd}(\mathrm{OAc})_{2} 1\right.$ $\mathrm{mol} \%$ and DPEphos $1.1 \mathrm{~mol} \%$ ) is worth noting and further demonstrates the crucial role of ligand on the course of this reaction.

The ligand-controlled regiodivergency observed during the palladium-catalyzed hydrogermylation of ynamides is not limited to triphenylgermanium hydride, as the triethyl- and tributyl-analogues demonstrated the same trend. Indeed, hydrogermylation of ynamide 1a using conditions $\mathbf{A 2}$ leads to $\alpha$-germylated enamides 3aa and 3ab with good selectivities $(\alpha / \beta=71: 29 \pm 1)$ while conditions $\mathbf{B} 2$ lead to the $\beta$-regioisomer $(\alpha / \beta$ up to $20: 80$ ). Importantly, we observed that this methodology is also applicable to the regiodivergent hydrostannylation of ynamides, a transformation that has been central to the construction of more complex scaffolds through Stille-type cross-couplings. ${ }^{28 \mathrm{e}-\mathrm{g}}$ As discussed in the introduction, this transformation is reported to always be 
$\alpha$-selective, especially with oxazolidinone-derived ynamides. ${ }^{28 c, f}$

Figure 1. X-ray structures $\beta, E-4 a, \alpha, E-3 \mathrm{r}$ and $\alpha, Z-5 q$.

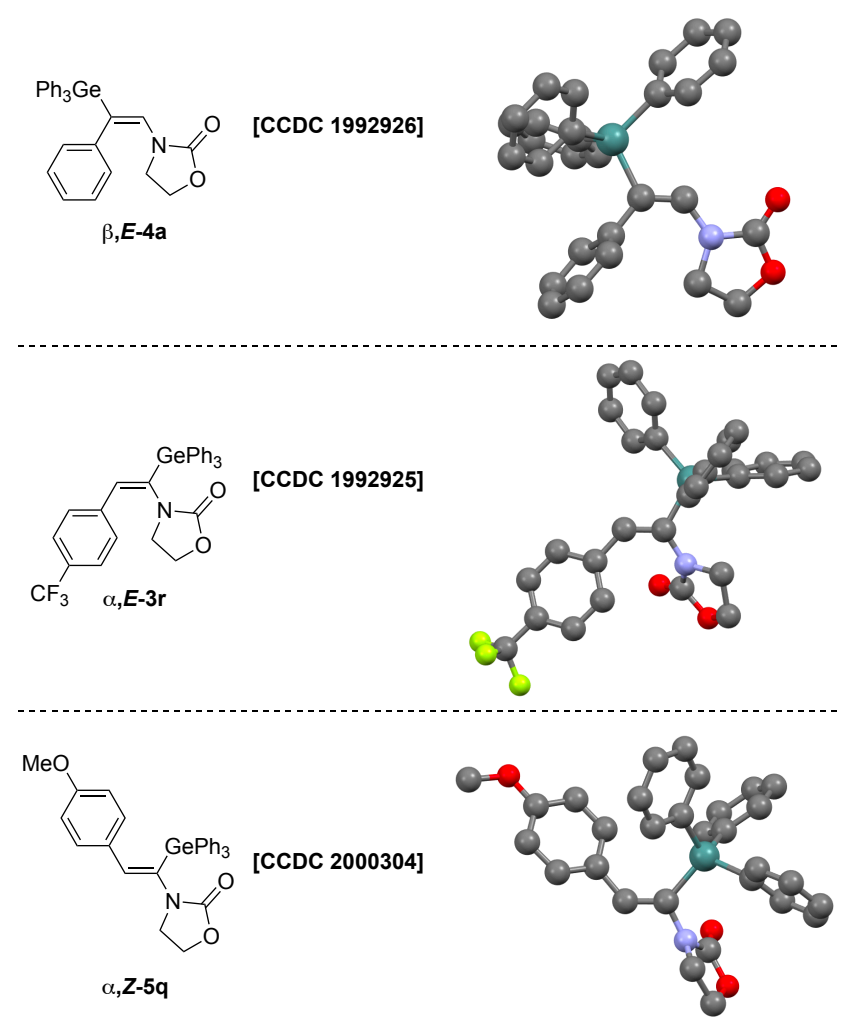

Under these newly developed conditions, excellent yields and selectivities are obtained during the hydrostannylation of ynamide 1a, either for the $\alpha$-isomer (3ac, $72 \%, \alpha / \beta=95: 5$, conditions A1) or the $\beta$-isomer (4ac, $82 \%, \alpha / \beta=5: 95$, conditions $\mathbf{A 2}$ ), thus allowing further functionalization, such as cross-coupling reactions, at either the $\alpha$ - or $\beta$-position of the stannylated enamide. ${ }^{36}$ Finally, it should be mentioned that unambiguous proof of the structures of the $\alpha$ - or $\beta$-germylated enamides were obtained through X-ray crystallographic studies of compounds $\mathbf{3 r}$, 4a and $\mathbf{5 q}$ (Figure 1). ${ }^{31,32}$

Proposed mechanism. The palladium-catalyzed hydrogermylation of ynamide is proposed to start by an oxidative addition of triphenylgermanium hydride $\mathbf{2}$ to palladium(0) complex I, leading to the palladium(II) complex II (Scheme 4a). The latter can coordinate to ynamide 1, leading to intermediates IIIa or IIIb, which can then undergo a hydropalladation step to IVa or IVb. With oxazolidinone-containing ynamides, a preference for formation of intermediate IVa is observed when $\mathrm{PPh}_{3}$ or DPEphos are used as ligands (conditions $\mathbf{A 1}$ or A2). Conversely, use of bulkier ligands such as $\mathrm{Cy}$ DPEphos or $\mathrm{P}(t-\mathrm{Bu})_{2} \mathrm{Me}$ (conditions $\mathrm{B} 1$ or $\left.\mathbf{B} 2\right)$ can over- ride this inherent selectivity, leading to preferential formation of intermediate $\mathbf{I V b}$. Final reductive elimination delivers the $\alpha, E$-isomer 3 or the $\beta, E$-isomer 4 .

As mentioned earlier, the hydrogermylation of ynamide $\mathbf{1 m}$ afforded an unexpected product $\mathbf{7 m}$ (Scheme 4a), the structure of which was assigned by extensive NMR investigations (see Supporting Information). Cyclized product $7 \mathrm{~m}$ provides some clues about the mechanism at play during the palladium-catalyzed hydrogermylation of ynamides. Indeed, whether a hydropalladation or a germylpalladation of the $\pi$-system is operative is a matter of debate. Although Oshima proposed a germylpalladation step as early as $1987,{ }^{18 a}$ we believe that a hydropalladation is favored which would explain the formation of $\mathbf{7 m}$ through successive migratory insertion of the carbon-palladium bond of IVa into the terminal alkene, followed by reductive elimination of VI.

Control experiments were also conducted on the hydrogermylation of ynamide 1a by triphenylgermanium hydride 2a, by varying the nature of the palladium complex $(\mathrm{Pd}(\mathrm{II})$ or $\operatorname{Pd}(0))$ and the nature of the ligand (and its loading) (Scheme 4b). Under conditions A2 (entry 1), $\mathrm{Pd}(\mathrm{OAc})_{2}$ and DPEphos (1:1.1) react in situ to generate a $\operatorname{Pd}(0)$ complex with the DPEphos mono-oxide $(\mathrm{DPEphos}(\mathrm{O}))^{33}$ ligand which can be considered a hemilabile bidentate ligand. ${ }^{37}$

Higher or lower loading of DPEphos proved to be detrimental for the reactivity or selectivity. $[\operatorname{Pd}(0) D P E p h o s(O)]$ was confirmed to be a catalytically active complex thanks to control experiment with an independently prepared DPEphos(O) ligand and $\mathrm{Pd}_{2}(\mathrm{dba})_{3}(1: 1)$ (Entry 2). The exact same selectivity as in Entry 1 was obtained $(\alpha, E-\mathbf{3 a} / \beta, E-\mathbf{4 a}=91: 9)$. On the other hand, the combination of $\mathrm{Pd}_{2}(\mathrm{dba})_{3}$ and DPEphos (1:1) generates an inactive complex for this reaction (Entry 3). For conditions B2 (Entries 4-7), similar conversions and selectivities were observed with a $\operatorname{Pd}(0) / \mathrm{P}(t-\mathrm{Bu})_{2} \mathrm{Me}$ ratio from 1:4 to $1: 1$, meaning that the active catalytic system is likely the monoligated palladium complex $\left[\mathrm{Pd}(0) \mathrm{P}(t-\mathrm{Bu})_{2} \mathrm{Me}\right]$. In both conditions, we assume that the regioselectivity of the hydropalladation is controlled by the ligand, and more especially by the substitution of the phosphorous by phenyl (A1, A2) or bulky alkyl groups (B1, B2). Finally, it should be noted that no conversion was observed in the absence of palladium catalyst, even after 31 days at $20^{\circ} \mathrm{C}$ (Entry 8). 


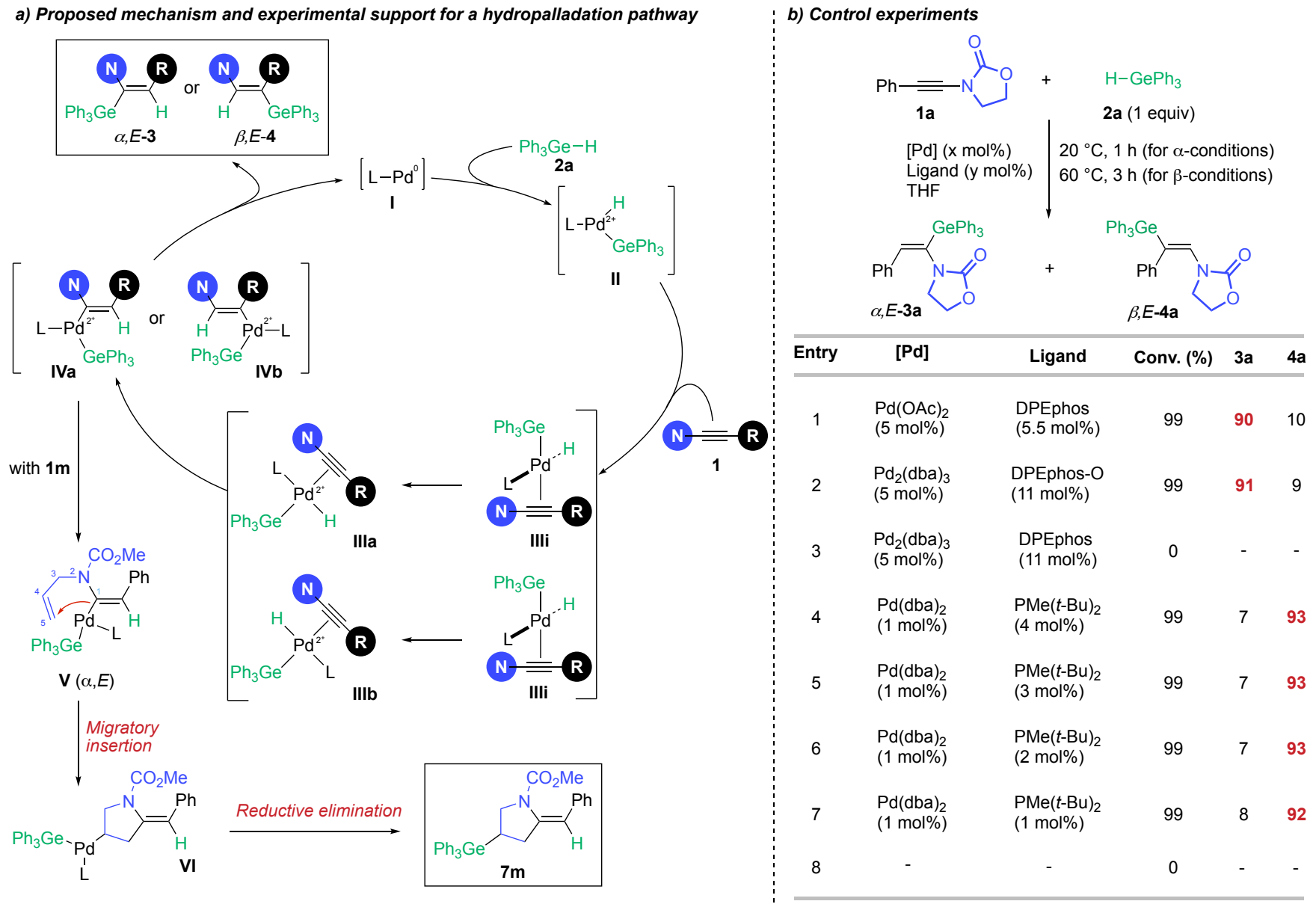

DFT calculations. Density functional theory (DFT) calculations were performed to explore the role of the ligand and its effect on selectivity. The selectivitydetermining and rate-determining step involving migratory insertion was computed in model systems and with full ligands. All optimizations were performed with B3LYP-D3/6-31G(d)-LANL2DZ(Pd), and energies reported are for B3LYP-D3/6-311+G(d,p)$\mathrm{SDD}(\mathrm{Pd}), \mathrm{SMD}(\mathrm{THF})$ single point calculations on the optimized geometries. Oxazolidinone-containing substrate 1a was used for the calculations below.

The addition of $\mathrm{Ge}-\mathrm{H}$ across the alkyne could proceed via two distinct mechanistic pathways: hydropalladation, followed by reductive elimination to form the $\mathrm{C}-\mathrm{Ge}$ bond, or germylpalladation, followed by reductive elimination to form the $\mathrm{C}-\mathrm{H}$ bond. Using a model system wherein the $\mathrm{P}$ and Ge ligands are simplified to $\mathrm{PH}_{3}$ and $\mathrm{GeH}_{3}$, we analyzed the possibility of these two mechanisms (Scheme 5). It was determined that the transition state barrier toward formation of the $\alpha$ product via a hydropalladation pathway was $6.0 \mathrm{kcal} / \mathrm{mol}$ (pathway a); the transition state barrier toward formation of the $\beta$ product was $8.0 \mathrm{kcal} / \mathrm{mol}$ (pathway b).

In the transition state for the formation of the $\alpha$ product, the atoms of the oxazolidinone are in the same plane as the four atoms involved in the transition state of the migratory insertion reaction $(\mathrm{C}-\mathrm{N}-\mathrm{C}-\mathrm{C}$ dihedral angle of $4^{\circ}$ ). The $p$ orbital of the $\mathrm{N}$ is thus not aligned with the forming $\mathrm{C}-\mathrm{H} \sigma$ bond. This suggests a preference during the transition state for conjugation of the $N \pi$ system with the fully formed $\pi$ system of the $\mathrm{C}=\mathrm{C}$, and the $\mathrm{C}=\mathrm{O}$ bond of the oxazolidinone, as opposed to the partially formed $\mathrm{C}-\mathrm{H} \sigma$ bond. In addition, a lack of interaction between these orbitals is in accord with the hydricity of the reacting $\mathrm{H}$. In the case of the $\beta$ transition state, the $\mathrm{C}-\mathrm{N}-\mathrm{C}-\mathrm{C}$ dihedral angle increases to $48^{\circ}$, leading to a greater degree of interaction between the $\mathrm{N}$ lone pair and the forming C-Pd $\sigma$ bond. 
Scheme 5. DFT calculations of hydropalladation and germylpalladation mechanisms with simplified ligands $\left(\mathrm{PH}_{3}, \mathrm{GeH}_{3}\right)$

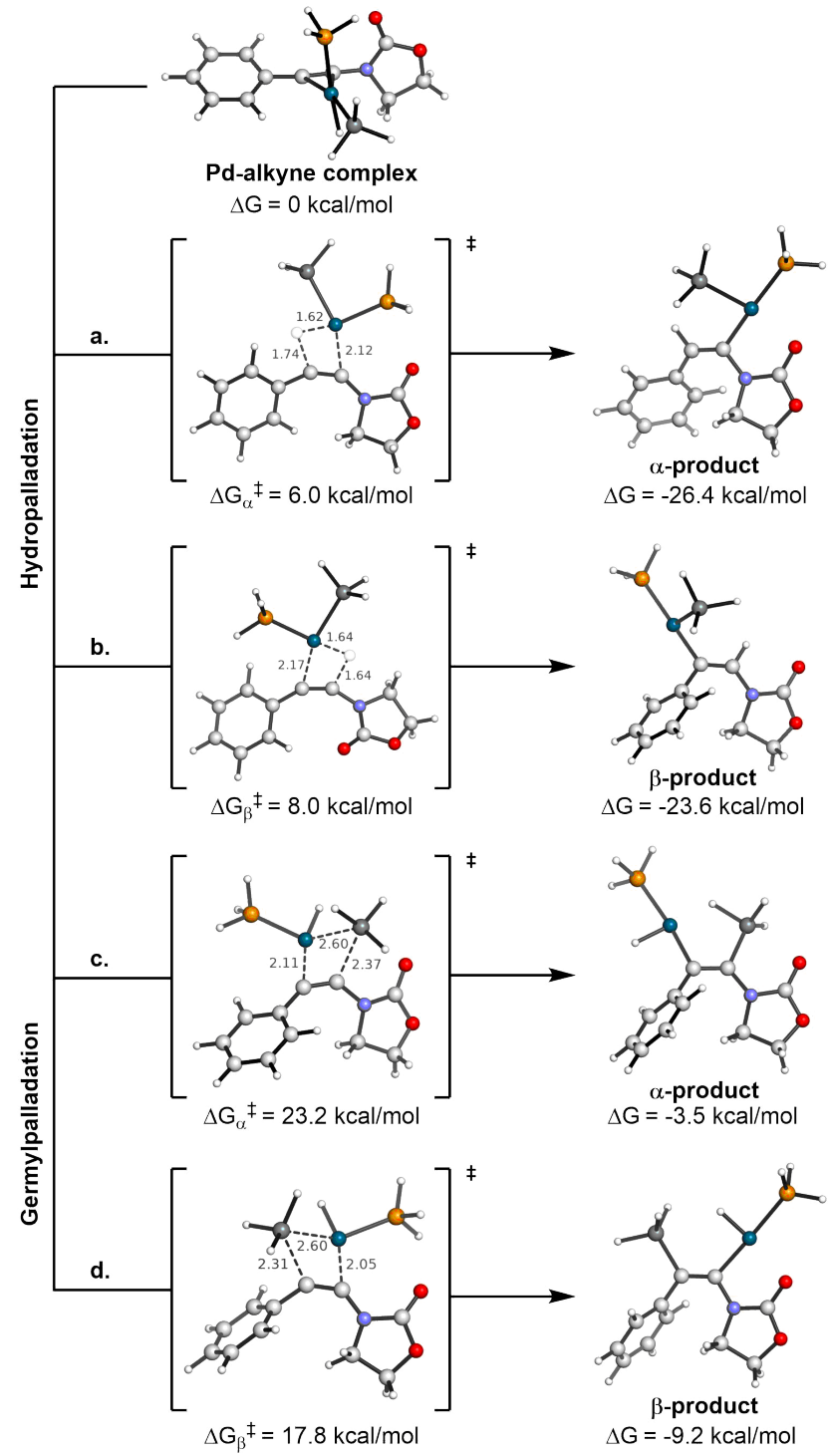

Analogous calculations were performed with substrate 1h, which contains a sulfonamide group instead of an oxazolidinone. For this substrate, also using $\mathrm{PH}_{3}$ and $\mathrm{GeH}_{3}$ as ligands, a reversal of selectivity was observed - the $\beta$ product was preferred by $0.9 \mathrm{kcal} / \mathrm{mol}$. In the case of the $\beta$ transition state, the $\mathrm{S}-\mathrm{N}-\mathrm{C}-\mathrm{C}$ dihedral angle was even larger, $76^{\circ}$, leading to greater alignment of the $p$ orbital of $\mathrm{N}$ and the forming $\mathrm{C}-\mathrm{Pd} \sigma$ bond.

Scheme 6. DFT calculations of hydropalladation and germylpalladation with a $\mathbf{P P h}_{3}$ ligand

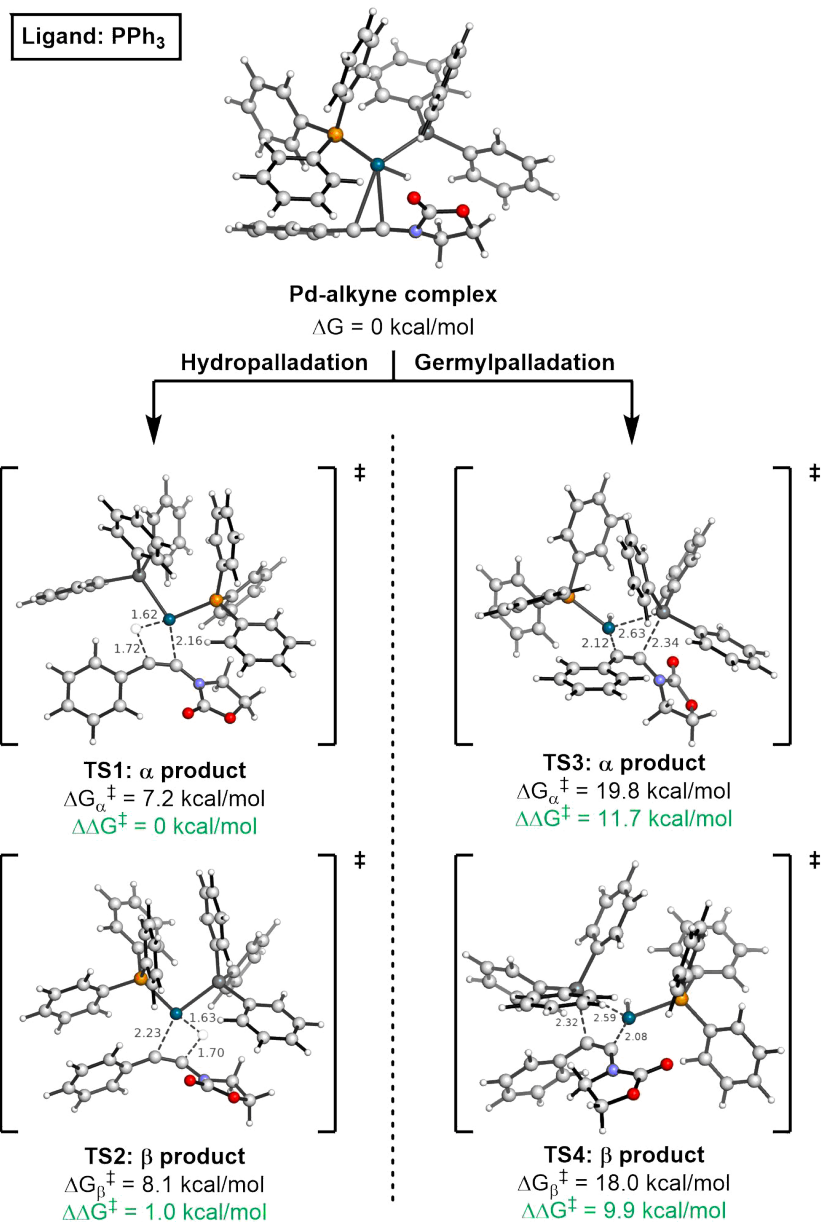

The preference for formation of the $\beta$ product is in agreement with experimental data, where the $\beta$ product is observed as the major product with all ligands that were evaluated (Scheme 2, ynamides $\mathbf{1 h}, \alpha / \beta=25: 75$ under Conditions A2; ynamides $\mathbf{1 h}-\mathbf{l}, \alpha / \beta=0: 100$ under Conditions B1 or B2). These data suggest that the difference in preference for formation of the $\alpha$ or $\beta$ product in the cases of the oxazolidinone substrate (1a) and sulfonamide substrate (1h) may be due to a difference in the extent of resonance of the $\mathrm{N}$ lone pair with the alkyne vs. the $\mathrm{C}=\mathrm{O}$ or $\mathrm{S}=\mathrm{O}$ bond.

In the sulfonamide substrate, a greater degree of donation of the $\mathrm{N}$ lone pair to the $\pi$ system of the reacting alkyne leads to a greater preference for the formation of the $\mathrm{C}-\mathrm{Pd}$ bond at the $\beta$ carbon. Conversely, a lesser degree of conjugation of the $\mathrm{N}$ lone pair with the $\pi$ system of the alkyne leads to the oxazolidinone acting as a better inductively withdrawing group than a resonancedonor. 
Investigation of the germylpalladation pathway for the oxazolidinone substrate revealed transition states that were significantly higher in energy: 23.2 and 17.8 $\mathrm{kcal} / \mathrm{mol}$ for the $\alpha$ and $\beta$ products, respectively (Scheme 5, pathways $\mathrm{c}$ and $\mathrm{d}$ ). These calculations show that the most favorable reaction pathway proceeds via hydropalladation, with preferential formation of the $\alpha$ product.

Scheme 7. DFT calculations of hydrogermylation with $\mathbf{P}(t-$ $\mathrm{Bu})_{2} \mathrm{Me}$ and $\mathrm{PMe}_{3}$ ligands

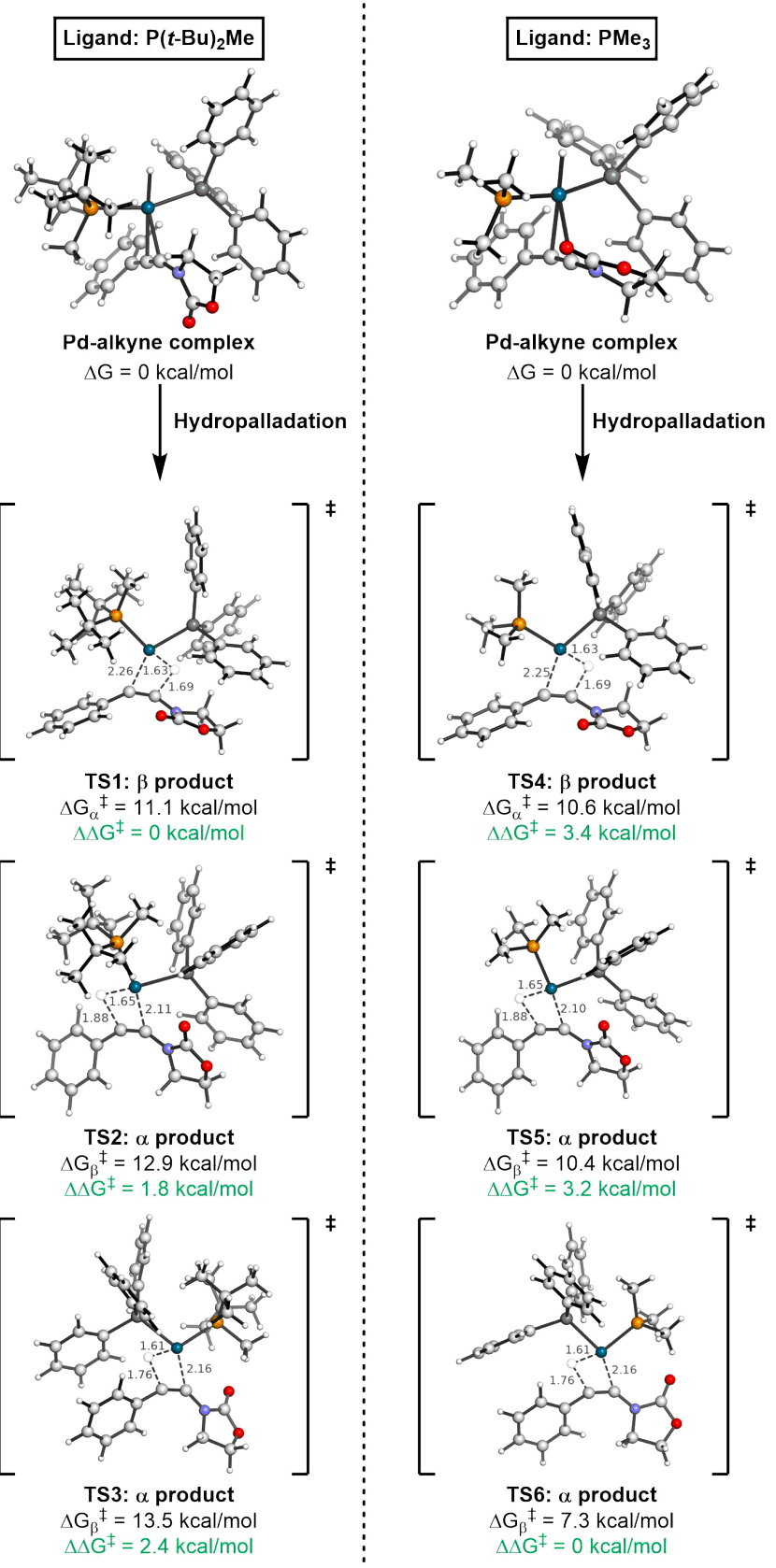

Analysis of the dihedral angle between the reacting atoms of the transition states revealed differing patterns for hydropalladation and germylpalladation.
In the transition states of the hydropalladation pathway, the forming $\mathrm{Pd}-\mathrm{C}$ and $\mathrm{C}-\mathrm{H}$ bonds are all in the same plane, with only a $1-3^{\circ}$ dihedral angle between the $\mathrm{Pd}-\mathrm{C}-\mathrm{C}-\mathrm{H}$ bonds (Scheme 5). Conversely, in the transition states for the germylpalladation pathway, the planes of the forming $\mathrm{Pd}-\mathrm{C}$ bond and $\mathrm{C}-\mathrm{Ge}$ bond are at a 46$63^{\circ}$ angle to each other ( $\mathrm{Pd}-\mathrm{C}-\mathrm{C}-\mathrm{Ge}$ dihedral angle).

This distortion of the dihedral angle is required in order for the Pd to adopt the angle required for the migratory insertion step of these reactions (approximately $75^{\circ}$ in all cases calculated) with respect to the alkyne, where the $\mathrm{Pd}-\mathrm{Ge}$ bond is significantly longer than the $\mathrm{Pd}-\mathrm{H}$ bond in the hydropalladation pathway (2.6 vs $1.6 \AA$ ). In addition to the high-energy transition states, the products of the germylpalladation reaction were also significantly higher in energy than those of hydropalladation. These trends held in the case of the $\mathrm{PPh}_{3}$ and $\mathrm{GePh}_{3}$ ligands as well, as discussed below.

Calculations of the transition states leading to the two pairs of regioisomers, with $\mathrm{PPh}_{3}$ (Scheme 6) and $\mathrm{P}(t$ $\mathrm{Bu})_{2} \mathrm{Me}$ (Scheme 7) as ligand, revealed a preference for the reaction with the $\mathrm{PPh}_{3}$ ligand to form the $\alpha$ product, and the reaction with $\mathrm{P}(t-\mathrm{Bu})_{2} \mathrm{Me}$ as ligand to form the $\beta$ product, which was consistent with experimental results.

When $\mathrm{PPh}_{3}$ was used as the ligand (Scheme 6), the transition state barrier to the $\alpha$ product was $7.2 \mathrm{kcal} / \mathrm{mol}$ (TS1), compared to the $8.1 \mathrm{kcal} / \mathrm{mol}$ barrier to the $\beta$ product (TS2). These results were consistent with the selectivity observed in the reaction with simplified ligands $\mathrm{PH}_{3}$ and $\mathrm{GeH}_{3}$ (Scheme 5). In addition, they were in good agreement with the experimental $\alpha: \beta$ ratio of 80:20 (Table 1, conditions A1). In both cases, the migratory insertion reaction was highly exergonic $(\alpha:-26.5$ $\mathrm{kcal} / \mathrm{mol}, \beta:-25.7 \mathrm{kcal} / \mathrm{mol})$. The high transition state barriers toward germylpalladation also reflected the aforementioned results. Computational studies of the reductive elimination step revealed a low transition state barrier (for the $\alpha$ isomer, $\Delta \mathrm{G}=-19.7 \mathrm{kcal} / \mathrm{mol} ; \Delta \mathrm{G}^{*}=$ $6.8 \mathrm{kcal} / \mathrm{mol}$ ), indicating that the reductive elimination is not the rate-determining step.

Throughout the course of these calculations, it became evident that the transition states wherein the phosphine ligand is trans to the transferring $\mathrm{H}$ are lower in energy than those where the germyl ligand is trans. This effect was further analyzed by calculating the energies of the reactions with a simplified acetylene substrate, which would decouple the effects of the substituents appended to the alkyne from the inherent preference of the trans ligand. When using $\mathrm{PPh}_{3}$ as ligand, it was determined that positioning the phosphine ligand trans to the $\mathrm{H}$ was favorable by $3.0 \mathrm{kcal} / \mathrm{mol}$ in the transition state. The analogous difference in energies for the $\mathrm{P}(t-\mathrm{Bu})_{2} \mathrm{Me}$ ligand was $2.3 \mathrm{kcal} / \mathrm{mol}$. 
With $\mathrm{P}(t-\mathrm{Bu})_{2} \mathrm{Me}$ as ligand, the experimentally observed major product was the $\beta$ product (Table 1, conditions B2), which was consistent with computational results (Scheme 7). The energy of the transition state to form the $\beta$-product (TS1) was $1.8 \mathrm{kcal} / \mathrm{mol}$ lower in energy than the transition state for the $\alpha$-product (TS2), which was in good agreement with the experimental selectivity $(7: 93 \alpha: \beta)$. The energies of the migratory insertion products were -24.6 and $-23.5 \mathrm{kcal} / \mathrm{mol}$ for the $\alpha$ and $\beta$ products, respectively. The $\beta$-TS structure can adopt the preferred geometry in which the phosphine ligand is trans to the $\mathrm{H}$ undergoing migratory insertion. Upon calculating the transition state leading to the minor product $\alpha$, however, we observed a preference for the phosphine ligand to be positioned trans to the reacting alkyne, and the germyl ligand to be trans to the transferring hydride, which was in contrast to all other optimized transition state structures.

Optimization of an $\alpha$-TS structure with the phosphine ligand trans to the $\mathrm{H}$ (TS3) revealed an energy 0.6 $\mathrm{kcal} / \mathrm{mol}$ higher than the $\alpha$-TS structure with the germyl group trans (TS2).

Calculations were undertaken in order to analyze the effects of electronics vs sterics on selectivity. First, electronic effects were studied by forming a Hammett series to determine whether a correlation exists between the electron-donating nature of the phosphine ligand and the $\alpha: \beta$ selectivity.

The $\alpha$ and $\beta$ transition states were calculated for the reaction with phosphine ligands $\mathrm{P}\left(p-\mathrm{NO}_{2} \mathrm{Ph}\right)_{3}$ and $\mathrm{P}(p$ $\mathrm{OHPh})_{3}$. In both of these cases, as with the $\mathrm{PPh}_{3}$ ligand, there was a preference for formation of the $\alpha$ product. The preference for the $\alpha$ product vs the $\beta$ product, for ligands $\mathrm{P}\left(p-\mathrm{NO}_{2} \mathrm{Ph}\right)_{3}, \mathrm{PPh}_{3}$, and $\mathrm{P}(p-\mathrm{OHPh})_{3}$, was 2.2, 1.0 , and $1.4 \mathrm{kcal} / \mathrm{mol}$, respectively. These results suggest that electronic properties of the phosphine ligand do not play the principal role in determining selectivity.

Steric effects were analyzed by substituting the $\mathrm{P}(t$ $\mathrm{Bu})_{2} \mathrm{Me}$ ligand for a $\mathrm{PMe}_{3}$ ligand, which would have similar electronic properties but very different steric properties (Scheme 7). The smaller size of the $\mathrm{PMe}_{3}$ ligand would thus provide an insight into the steric effects of the bulky $t$-Bu groups. Whereas use of the $\mathrm{P}(t$ $\mathrm{Bu})_{2} \mathrm{Me}$ ligand led to preferential formation of the $\beta$ product, use of the $\mathrm{PMe}_{3}$ ligand led to reversal of selectivity, with a $3.4 \mathrm{kcal} / \mathrm{mol}$ preference for the $\alpha$ product (TS6). In addition, with the steric hindrance imparted by the $t$-Bu groups now removed, there was a significant preference for the geometry where the phosphine is trans to the H (TS6), compared to the Ge being trans (TS5). These steric factors are further evidenced by the distortion of the Ge-Pd-P angle in TS3 $\left(109^{\circ}\right)$, returning to an angle of $97^{\circ}$ in TS6, which is more akin to the angle in all other lower energy transition states.
Scheme 8. Two-step synthesis of germylated isoquinolinones from ynamide $1 \mathrm{z}$

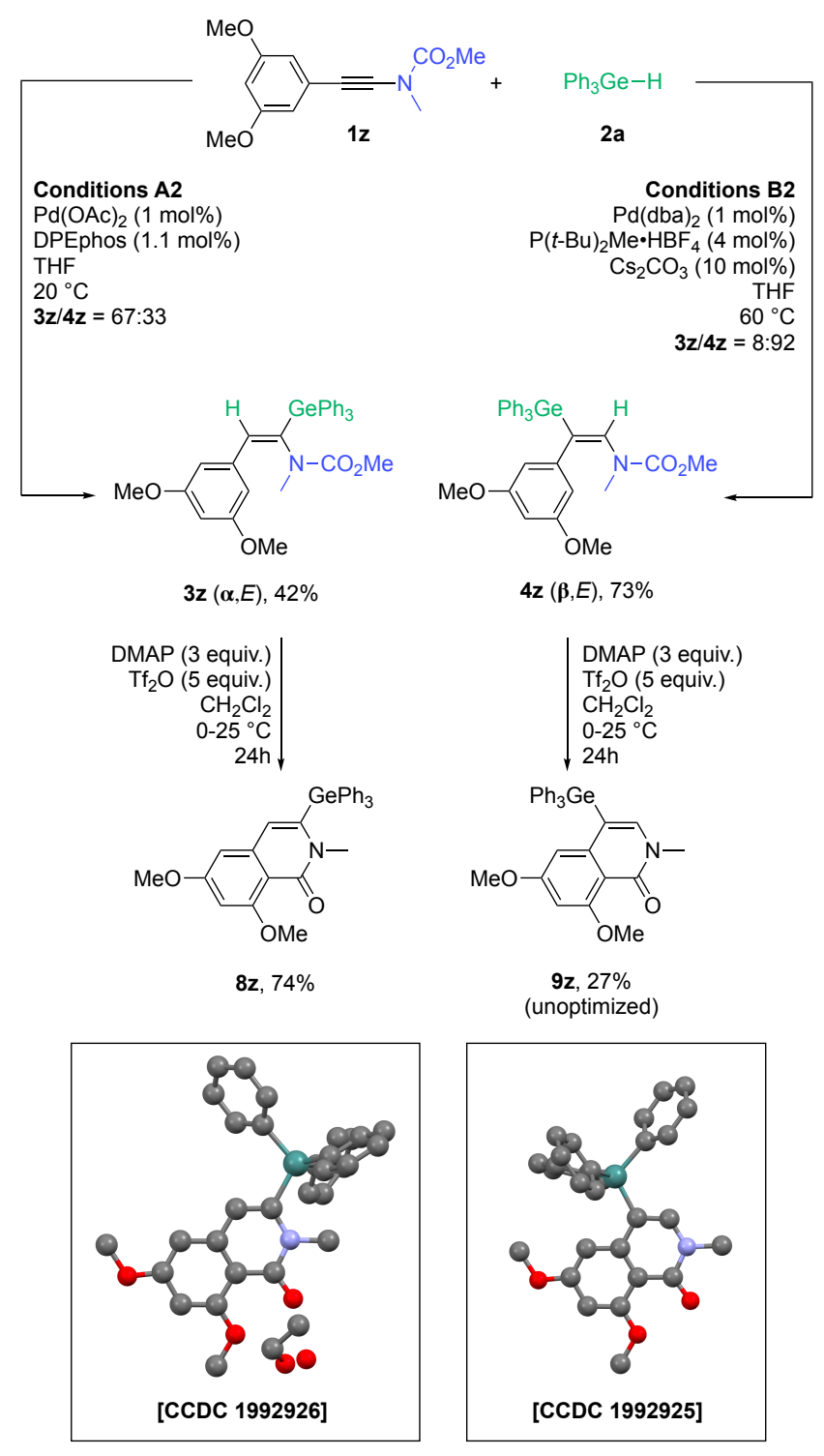

In both of the two lowest-energy transition states with the $\mathrm{P}(t-\mathrm{Bu})_{2} \mathrm{Me}$ ligand, TS1 and TS2, the less bulky $\mathrm{GePh}_{3}$ group occupies the position closer to the more bulky oxazolidinone. Conversely, in TS3, the bulky phosphine is near the bulkier oxazolidinone, leading to unfavorable steric interactions. TS1 is preferable to TS2 due to the trans-arrangement between the phosphine and $\mathrm{H}$ ligands, an arrangement which is unfavorable in the case of formation of the $\alpha$ product (TS3) due to steric interactions.

Taken together, the results of these calculations suggest that, in the case of the bulkier $\mathrm{P}(t-\mathrm{Bu})_{2} \mathrm{Me}$ ligand (Tolman cone angle: $161^{\circ}$ ), ${ }^{38}$ unfavorable steric interactions between the ligand and the ynamide play a key role in reversing selectivity. 
In the case of the less bulky $\mathrm{PPh}_{3}$ ligand (Tolman cone angle: $\left.145^{\circ}\right),{ }^{38}$ the selectivity mirrors that determined for the case of the $\mathrm{PH}_{3}$ and $\mathrm{GeH}_{3}$ ligands, where ligandinduced steric hindrance is diminished. These smaller $\mathrm{PPh}_{3}$ ligands can easily adopt the geometry that is preferable both sterically and electronically. In addition, due to the comparable size of the $\mathrm{PPh}_{3}$ and $\mathrm{GePh}_{3}$ ligands, these two ligands can easily interchange to create the most preferable geometry. Both the $\alpha$ and $\beta$ transition states can thus benefit from the favorable orientation where the phosphine is trans to the $\mathrm{H}$ that undergoes migratory insertion.

Synthesis of germylated heterocycles. To showcase the synthetic potential of the ligand-controlled regiodivergent palladium-catalyzed hydrogermylation of ynamides, the rapid preparation of representative germylated heterocycles was studied (Scheme 8). Ynamide $\mathbf{1 z}$ was converted into the $\alpha$ - and $\beta$-germylated enamides $\mathbf{3 z}$ and $\mathbf{4 z}$ through conditions $\mathbf{A 2}(\alpha / \beta=67: 33)$ and $\mathbf{B} 2(\alpha / \beta=8: 92)$, respectively. Bischler-Napieralski reactions of $\mathbf{3 z}$ and $\mathbf{4 z}$ using DMAP and triflic anhydride in dichloromethane ${ }^{39}$ delivered the desired germylated isoquinolinones $\mathbf{8 z}$ (74\%) and $\mathbf{9 z}$ (27\%, unoptimized), the structures of which have been confirmed by X-ray crystallography.

\section{Conclusions}

We have developed a ligand-controlled palladiumcatalyzed regiodivergent hydrometallation reaction of ynamides, yielding selectively $\alpha, E$ - and $\beta, E$ - metallated enamides depending on the steric demand of the phosphine ligand. The influence of the substituents of the ynamide was studied, revealing a striking influence of the nature of the nitrogen electron withdrawing group of the ynamide. The synthetic relevance of $\alpha$ - and $\beta$ germylated enamides was briefly demonstrated for the synthesis of original germylated heterocycles. Experimental evidences and DFT calculations support a hydropalladation pathway, and that the regioselectivity can be controlled by the steric requirements of the phosphine ligands.

\section{ASSOCIATED CONTENT}

\section{Supporting Information}

The Supporting Information is available free of charge on the ACS Publications website at DOI: $10.1021 / \ldots$
X-ray crystallographic data for $\boldsymbol{\alpha}, \boldsymbol{E}-\mathbf{3 r}$ (CCDC 1992925) (CIF)

X-ray crystallographic data for $\boldsymbol{\beta}, \boldsymbol{E}-\mathbf{4 a}$ (CCDC 1992926) (CIF)

X-ray crystallographic data for $\boldsymbol{\alpha}, \boldsymbol{Z}-\mathbf{5 q}$ (CCDC 2000304) (CIF)

X-ray crystallographic data for $\mathbf{8 z ~ ( C C D C ~ 1 9 9 2 9 7 0 ) ~ ( C I F ) ~}$ X-ray crystallographic data for 9z (CCDC 1992927) (CIF) Experimental procedures, characterization data, and copies of NMR spectra for all products; computed energies and Cartesian coordinates of all the DFT-optimized structures (PDF)

\section{AUTHOR INFORMATION}

\section{Corresponding Author}

K. N. Houk: houk@chem.ucla.edu

N. Blanchard: n.blanchard@unistra.fr

V. Bizet: vbizet@unistra.fr

\section{Author Contributions}

The manuscript was written through contributions of all authors.

\#V. Debrauwer and A. Turlik contributed equally as first authors.

\section{Notes}

The authors declare no competing financial interests.

\section{ACKNOWLEDGMENT}

This work is supported by the ANR HydroMet project, ANR-18-CE07-0020 grant of the French National Research Agency (ANR), the CNRS, the Universite de HauteAlsace, the Université de Strasbourg. The authors are grateful to the National Science Foundation (grant CHE1764328) for financial support. Calculations were performed on the Hoffman2 cluster at the University of California, Los Angeles, and the Extreme Science and Engineering Discovery Environment (XSEDE), which is supported by the National Science Foundation (grant OCI1053575). The authors warmly thank David Thiébaut for preliminary investigations using conditions $\mathbf{A 1}$ and their former colleague Dr. P. Bisseret for inspiring discussions. We also thank the anonymous reviewers for careful readings and constructive comments.

\section{REFERENCES}

1. Cordovilla, C.; Bartolomé, C.; Martínez-Ilarduya, J. M.; Espinet, P., The Stille Reaction, 38 Years Later. ACS Catal. 2015, 5, 3040-3053.

2. Denmark, S. E.; Sweis, R., F., In Metal-Catalyzed Cross-Coupling Reactions, (ed. Armin de Meijere, François Diederich) pp 163-216 (Wiley, 2004).

3. a) Spivey, A. C.; Gripton, C. J. G.; Hannah, J. P., Recent Advances in Group 14 Cross-Coupling: Si and Ge-Based Alternatives to the Stille Reaction. Curr. 
Org. Synth. 2004, 1, 211-226; b) Song, H.-J.; Jiang, W.-T.; Zhou, Q.-L.; Xu, M.-Y.; Xiao, B., StructureModified Germatranes for Pd-Catalyzed Biaryl Synthesis. ACS Catal. 2018, 8, 9287-9291; c) Xu, M.-Y.; Jiang, W.-T.; Li, Y.; Xu, Q.-H.; Zhou, Q.-L.; Yang, S.; Xiao, B., Alkyl Carbagermatranes Enable Practical Palladium-Catalyzed sp2-sp3 Cross-Coupling. $J$. Am. Chem. Soc. 2019, 141, 7582-7588; d) Fricke, C.; Sherborne, G. J.; Funes-Ardoiz, I.; Senol, E.; Guven, S.; Schoenebeck, F., Orthogonal Nanoparticle Catalysis with Organogermanes. Angew. Chem. Int. Ed. 2019, 58, 17788-17795: e) Fricke, C.; Dahiya, A.; Reid, W. B.; Schoenebeck, F., Gold-Catalyzed C-H Functionalization with Aryl Germanes. ACS Catal. 2019, 9, 9231-9236; f) Fricke, C.; Dahiya, A.; Reid, W. B.; Schoenebeck, F., Correction to "GoldCatalyzed C-H Functionalization with Aryl Germanes". ACS Catal. 2019, 9, 10232-10232; g) Dahiya, A.; Fricke, C.; Schoenebeck, F., Gold-Catalyzed Chemoselective Couplings of Polyfluoroarenes with Aryl Germanes and Downstream Diversification. $J$. Am. Chem. Soc. 2020, 142, 7754-7759; h) Sherborne, G. J.; Gevondian, A. G.; Funes-Ardoiz, I.; Dahiya, A.; Fricke, C.; Schoenebeck, F., Modular \& Selective Arylation of Aryl Germanes (C-GeEt3) over C-Bpin, $\mathrm{C}-\mathrm{SiR} 3$ and Halogens enabled by Light-Activated Gold-Catalysis. Angew. Chem. Int. Ed., 2020, Early view, DOI: 10.1002/anie.202005066.

4. Ramesh, R.; Reddy, D. S., Quest for Novel Chemical Entities through Incorporation of Silicon in Drug Scaffolds. J. Med. Chem. 2018, 61, 3779-3798.

5. a) Fujii, S., Expanding the chemical space of hydrophobic pharmacophores: the role of hydrophobic substructures in the development of novel transcription modulators. MedChemComm 2016, 7, 10821092; b) Tacke, R.; Heinrich, T.; Kornek, T.; Merget, M.; Wagner, S. A.; Gross, J.; Keim, C.; Lambrecht, G.; Mutschler, E.; Beckerss, T.; Bernd, M.; Reissmann, T., Bioorganogermanium Chemistry: Studies on $\mathrm{C} / \mathrm{Si} / \mathrm{Ge}$ Bioisosterism. Phosphorus, Sulfur, and Silicon Relat. Elem. 1999, 150, 69-87; c) Menchikov, L. G.; Ignatenko, M. A., Biological Activity of Organogermanium Compounds (A Review). Pharm. Chem. J. 2013, 46, 635-638.

6. Johnson, T. W.; Gallego, R. A.; Edwards, M. P., Lipophilic Efficiency as an Important Metric in Drug Design. J. Med. Chem. 2018, 61, 6401-6420.

7. Yamakawa, T.; Kagechika, H.; Kawachi, E.; Hashimoto, Y.; Shudo, K., Retinobenzoic acids. 5. Retinoidal activities of compounds having a trimethylsilyl or trimethylgermyl group(s) in human promyelocytic leukemia cells HL-60. J. Med. Chem. 1990, 33, 1430-1437.

8. Fujii, S.; Miyajima, Y.; Masuno, H.; Kagechika, H., Increased Hydrophobicity and Estrogenic Activity of Simple Phenols with Silicon and GermaniumContaining Substituents. J. Med. Chem. 2013, 56, 160-166.

9. a) Ichinose, Y.; Nozaki, K.; Wakamatsu, K.; Oshima, $\mathrm{K}$.; Utimoto, K., $\mathrm{Et}_{3} \mathrm{~B}$ induced stereoselective radical addition of $\mathrm{Ph}_{3} \mathrm{GeH}$ to acetylenes and its application to isomerization of olefins. Tetrahedron Lett. 1987, 28, 3709-3712; b) Ichinose, Y.; Oshima, K.; Utimoto,
K., Application of Free Radical Substitution Reaction into Interconversion of 1-Alkenylsulfides, 1Alkenylgermanes, and 1-Alkenylstannanes. Chem. Lett. 1988, 17, 669-672; c) Nozaki, K.; Ichinose, Y.; Wakamatsu, K.; Oshima, K.; Utimoto, K., Et ${ }_{3} B$ Induced Stereoselective Radical Addition of $\mathrm{Ph}_{3} \mathrm{GeH}$ to Carbon-Carbon Multiple Bonds and Its Application to Isomerization of Olefins. Bull. Chem. Soc. Jpn. 1990, 63, 2268-2272; d) Taniguchi, M.; Oshima, K.; Utimoto, K., Triethylborane Induced Intramolecular Hydrogermylation of Homoallylic Alcohols and Homopropargylic Alcohols. Chem. Lett. 1993, 22, 1751-1754; e) Bernardoni, S.; Lucarini, M.; Pedulli, G. F.; Valgimigli, L.; Gevorgyan, V.; Chatgilialoglu, C., Addition Reactions of Tris(trimethylsilyl)germyl Radicals to Unsaturated Compounds. An EPR and Product Study. J. Org. Chem. 1997, 62, 8009-8014; f) Kinoshita, H.; Kakiya, H.; Oshima, K., Trialkylmanganate Mediated Radical Addition of Triphenylgermane to Carbon-Carbon Multiple Bonds. Bull. Chem. Soc. Jpn. 2000, 73, 2159-2160; g) for ultrasound promoted hydrogermylation, that likely proceeds through a radical pathway, see: David-Quillot, F.; Thiéry, V.; Abarbri, M.; Thibonnet, J.; Besson, T.; Duchéne, A., Regio- and Stereoselective Synthesis of (Z)-Vinylgermanes by Hydrogermylation of Alkynes. In Main Group Metal Chem. 2007, 30, 235-244.

10. Piers, E.; Lemieux, R. M., Novel (Trimethylgermyl)copper(I) Reagents: Preparation and Addition to $\alpha, \beta$-Unsaturated Ketones and $\alpha, \beta$-Alkynic Esters. Organometallics 1998, 17, 4213-4217.

11. a) Marciniec, B.; Lawicka, H.; Dudziec, B., New Catalytic Route to Alkynylgermanes. Organometallics 2007, 26, 5188-5192; b) Rzonsowska, M.; Kownacki, I.; Dudziec, B.; Marciniec, B., Iridium complex catalyzed germylative coupling reaction between alkynes and iodogermanes-a new route to alkynylgermanium and alkynylgermasilicon compounds. Dalton Trans. 2014, 43, 16795-16799.

12. a) Komami, N.; Matsuoka, K.; Yoshino, T.; Matsunaga, S., Palladium-Catalyzed Germylation of Aryl Bromides and Aryl Triflates Using Hexamethyldigermane. Synthesis 2018, 50, 2067-2075; b) Wollenburg, M.; Bajohr, J.; Marchese, A. D.; Whyte, A.; Glorius, F.; Lautens, M., Palladium-Catalyzed Disilylation and Digermanylation of Alkene Tethered Aryl Halides: Direct Access to Versatile Silylated and Germanylated Heterocycles. Org. Lett. 2020, 22, 3679-3683.

13. Schwier, T.; Gevorgyan, V., Trans- and Cis-Selective Lewis Acid Catalyzed Hydrogermylation of Alkynes. Org. Lett. 2005, 7, 5191-5194; b) Keess, S.; Oestreich, M., Access to Fully Alkylated Germanes by $\mathrm{B}\left(\mathrm{C}_{6} \mathrm{~F}_{5}\right)_{3}$-Catalyzed Transfer Hydrogermylation of Alkenes. Org. Lett. 2017, 19, 1898-1901.

14. Liang, H.; Ji, Y.-X.; Wang, R.-H.; Zhang, Z.-H.; Zhang, B., Visible-Light-Initiated ManganeseCatalyzed E-Selective Hydrosilylation and Hydrogermylation of Alkynes. Org. Lett. 2019, 21, 2750-2754.

15. a) Itazaki, M.; Kamitani, M.; Nakazawa, H., Transselective hydrogermylation of alkynes promoted by methyliron and bis(germyl)hydridoiron complexes as 
a catalyst precursor. Chem. Commun. 2011, 47, 78547856; b) Greenhalgh, M. D.; Thomas, S. P., Chemo-, regio-, and stereoselective iron-catalysed hydroboration of alkenes and alkynes. Chem. Commun. 2013, 49, 11230-11232.

16. a) Corriu, R. J. P.; Moreau, J. J. E., Stéréochimie de l'hydrogermylation des composés insaturés catalysée par des complexes du rhodium et du platine : II. Hydrogermylation des acètylèniques. J. Organomet. Chem. 1972, 40, 97-105; b) Wada, F.; Abe, S.; Yonemaru, N.; Kikukawa, K.; Matsuda, T., Catalytic Behavior of Rhodium(I) Complexes in Hydrogermylation and Hydrosilylation of Phenylacetylene. Bull. Chem. Soc. Jpn. 1991, 64, 1701-1703; c) Faller, J. W.; Kultyshev, R. G., One-Step Syntheses of Styryl Germatranes via Rhodium- or PalladiumCatalyzed Hydrogermylation of Arylacetylenes by $\mathrm{HGe}\left(\mathrm{OCH}_{2} \mathrm{CH}_{2}\right)_{3} \mathrm{~N}$. Organometallics 2002, 22, 199202.

17. a) Matsuda, T.; Kadowaki, S.; Yamaguchi, Y.; Murakami, M., Ruthenium-Catalyzed transHydrogermylation of Alkynes: Formation of 2,5Disubstituted Germoles through Double transHydrogermylation of 1,3-Diynes. Org. Lett. 2010, 12, 1056-1058; b) Roşca, D.-A.; Radkowski, K.; Wolf, L. M.; Wagh, M.; Goddard, R.; Thiel, W.; Fürstner, A., Ruthenium-Catalyzed Alkyne transHydrometalation: Mechanistic Insights and Preparative Implications. J. Am. Chem. Soc. 2017, 139, 2443-2455.

18. a) Ichinose, Y.; Oda, H.; Oshima, K.; Utimoto, K., Palladium Catalyzed Hydrostannylation and Hydrogermylation of Acetylenes. Bull. Chem. Soc. Jpn. 1987, 60, 3468-3470; b) Widenhoefer, R. A.; Vadehra, A.; Cheruvu, P. K., Cyclization/Hydrogermylation of Functionalized 1,6-Dienes Catalyzed by Cationic Palladium Complexes. Organometallics 1999, 18, 4614-4618; c) Kinoshita, H.; Nakamura, T.; Kakiya, H.; Shinokubo, H.; Matsubara, S.; Oshima, K., Remarkable Rate Acceleration of $\mathrm{Pd}(0)$-Catalyzed Hydrogermylation of Alkynes and Dienes in Water. Org. Lett. 2001, 3, 2521-2524; d) Liang, Y.; Pitteloud, J.P.; Wnuk, S. F., Hydrogermylation of 5-Ethynyluracil Nucleosides: Formation of 5-(2-Germylvinyl)uracil and 5-(2-Germylacetyl)uracil Nucleosides. J. Org. Chem. 2013, 78, 5761-5767; e) Pelzer, S.; Neumann, B.; Stammler, H.-G.; Ignat'ev, N.; Hoge, B., Tris(pentafluoroethyl)germane: Deprotonation and Hydrogermylation Reactions. Chem. Eur. J. 2017, 50, 12233-12242.

19. a) Lesbre, M.; Satgé, J., Action des dérivés acétyléniques sur les alcoylgermanes en présence d'acide chloroplatinique C.R. Acad. Sci. 1960, 250, 22202222; b) Dirnens, V.; Barabanov, D. I.; Liepiņš, E.; Ignatovich, L. M.; Lukevics, E., Amination of vinylsilanes and vinylgermanes containing an activated double bond. J. Organomet. Chem. 1992, 435, 257 263; c) Piers, E.; Lemieux, R., Platinum-catalysed addition of trimethylgermane to 1-trimethylsilylalk1-ynes: a convenient synthesis of functionalised 2trimethylgermylalk-1-enes. J. Chem. Soc., Perkin Trans. 1 1995, 3-5.
20. For reviews about hydrometallation of alkynes: a) Wolfsberger, W., Hydrogermylierungsreaktionen. $J$. Prakt. Chem. 1992, 334, 453-464; b) Frihed, T. G.; Fürstner, A., Progress in the trans-Reduction and trans-Hydrometalation of Internal Alkynes. Applications to Natural Product Synthesis. Bull. Chem. Soc. Jpn 2016, 89, 135-160; c) Dobbs, A. P.; Chio, F. K. I., Hydrometallation Group 4 ( $\mathrm{Si}, \mathrm{Sn}, \mathrm{Ge}$, and $\mathrm{Pb})$. In Comprehensive Organic Synthesis II (Second Edition) (ed Knochel P.), pp 964-998 (Elsevier, 2014).

21. Mazerolles, P.; Lesbre, M. Réactivité comparée des vinyl- et allylgermanes. Compte Rendu de l'Académie des Sciences 1959, 248, 2018-2020; b) Henry, M. C.; Downey, M. F. Triphenylgermane Addition Reactions. J. Org. Chem. 1961, 26, 2299-2300.

22. a) Yorimitsu, H.; Oshima, K., Recent advances in the use of tri(2-furyl)germane, triphenylgermane and their derivatives in organic synthesis. Inorg. Chem. Commun. 2005, 8, 131-142; b) Torres, N. M.; Lavis, J. M.; Maleczka Jr, R. E., Reactions of vinyltributylgermanes and aryl halides under Heck conditions. Tetrahedron Lett. 2009, 50, 4407-4410.

23. a) Fürstner, A., trans-Hydrogenation, gemHydrogenation, and trans-Hydrometalation of Alkynes: An Interim Report on an Unorthodox Reactivity Paradigm. J. Am. Chem. Soc. 2019, 141, 11-24; b) Rummelt, S. M.; Radkowski, K.; Roşca, D.-A.; Fürstner, A., Interligand Interactions Dictate the Regioselectivity of trans-Hydrometalations and Related Reactions Catalyzed by [Cp* RuCl]. Hydrogen Bonding to a Chloride Ligand as a Steering Principle in Catalysis. J. Am. Chem. Soc. 2015, 137, 5506-5519.

24. a) Cook, A. M.; Wolf, C., Terminal ynamides: synthesis, coupling reactions, and additions to common electrophiles. Tetrahedron Lett. 2015, 56, 2377-2392; b) Wang, X.-N.; Yeom, H.-S.; Fang, L.-C.; He, S.; Ma, Z.-X.; Kedrowski, B. L.; Hsung, R. P., Ynamides in Ring Forming Transformations. Acc. Chem. Res. 2014, 47, 560-578; c) Lu, T.; Hsung, R. P., Novel ynamide structural analogues and their synthetic transformations. ARKIVOC 2014, 127-141; d) Evano, G.; Jouvin, K.; Coste, A., General Amination Reactions for the Synthesis of Ynamides. Synthesis 2013, 45, 17-26; e) Evano, G.; Coste, A.; Jouvin, K., Ynamides: Versatile Tools in Organic Synthesis. Angew. Chem. Int. Ed. 2010, 49, 2840-2859; f) DeKorver, K. A.; Li, H.; Lohse, A. G.; Hayashi, R.; Lu, Z.; Zhang, Y.; Hsung, R. P., Ynamides: A Modern Functional Group for the New Millennium. Chem. Rev. 2010, 110, 5064-5106.

25. a) Le Fouler, V.; Duret, G.; Bisseret, P.; Blanchard, $\mathrm{N}$., Copper-mediated synthesis of $\mathrm{N}$-vinyl ynamide from N-vinyl carbamates. Tetrahedron Lett. 2018, 59, 3349-3352; b) Duret, G.; Le Fouler, V.; Bisseret, P.; Bizet, V.; Blanchard, N., Diels-Alder and Formal Diels-Alder Cycloaddition Reactions of Ynamines and Ynamides. Eur. J. Org. Chem. 2017, 6816-6830; c) Duret, G.; Quinlan, R.; Yin, B.; Martin, R. E.; Bisseret, P.; Neuburger, M.; Gandon, V.; Blanchard, N., Intramolecular Inverse Electron-Demand [4+2] $\mathrm{Cy}$ cloadditions of Ynamides with Pyrimidines: Scope and DFT Insights. J. Org. Chem. 2017, 82, 17261742; d) Donnard, M.; Duret, G.; Bisseret, P.; 
Blanchard, N., Intramolecular inverse electrondemand [4+2] cycloadditions of ynamidyl-tethered pyrimidines: Comparative studies in trifluorotoluene and sulfolane. C. R. Acad. Sci. 2017, 20, 643-647; e) Evano, G.; Blanchard, N.; Compain, G.; Coste, A.; Demmer, C. S.; Gati, W.; Guissart, C.; Heimburger, J.; Henry, N.; Jouvin, K.; Karthikeyan, G.; Laouiti, A.; Lecomte, M.; Martin- Mingot, A.; Métayer, B.; Michelet, B.; Nitelet, A.; Theunissen, C.; Thibaudeau, S.; Wang, J.; Zarca, M.; Zhang, C., A Journey in the Chemistry of Ynamides: from Synthesis to Applications. Chem. Lett. 2016, 45, 574-585; f) Duret, G.; Quinlan, R.; Martin, R. E.; Bisseret, P.; Neuburger, M.; Gandon, V.; Blanchard, N., Inverse Electron-Demand [4 + 2]-Cycloadditions of Ynamides: Access to Novel Pyridine Scaffolds. Org. Lett. 2016, 18, 1610-1613.

26. a) Romain, E.; Fopp, C.; Chemla, F.; Ferreira, F.; Jackowski, O.; Oestreich, M.; Perez-Luna, A., TransSelective Radical Silylzincation of Ynamides. Angew. Chem. Int. Ed. 2014, 53, 11333-11337; b) Kim, Y.; Dateer, R. B.; Chang, S., Borane-Catalyzed Selective Hydrosilylation of Internal Ynamides Leading to $\beta$-Silyl (Z)-Enamides. Org. Lett. 2017, 19, 190193; c) Zheng, N.; Song, W.; Zhang, T.; Li, M.; Zheng, Y.; Chen, L., Rhodium-Catalyzed Highly Regioselective and Stereoselective Intermolecular Hydrosilylation of Internal Ynamides under Mild Conditions. J. Org. Chem. 2018, 83, 6210-6216; d) Fopp, C.; Romain, E.; Isaac, K.; Chemla, F.; Ferreira, F.; Jackowski, O.; Oestreich, M.; Perez-Luna, A., Stereodivergent Silylzincation of $\alpha$-HeteroatomSubstituted Alkynes. Org. Lett. 2016, 18, 20542057.e) Vercruysse, S.; Jouvin, K.; Riant, O.; Evano, G., Copper-Catalyzed Silylcupration of Activated Alkynes. Synthesis 2016, 48, 3373-3381.

27. de la Vega-Hernández, K.; Romain, E.; Coffinet, A.; Bijouard, K.; Gontard, G.; Chemla, F.; Ferreira, F.; Jackowski, O.; Perez-Luna, A., Radical Germylzincation of $\alpha$-Heteroatom-Substituted Alkynes. J. Am. Chem. Soc. 2018, 140, 17632-17642.

28. a) Minière, S.; Cintrat, J.-C., New and Efficient Synthesis of Stannyl Enamines. Synthesis 2001, 705-707; b) Naud, S.; Cintrat, J.-C. New Stannyl Enamides. Synthesis 2003, 1391-1397; c) Buissonneaud, D.; Cintrat, J.-C., Highly regio- and stereocontrolled synthesis of $\beta$-substituted $\alpha$-tributylstannyl enamides. Tetrahedron Lett. 2006, 47, 3139-3143; d) Maity, P.; Klos, M. R.; Kazmaier, U., Syntheses of $\alpha-$ Stannylated and $\alpha$-Iodinated Enamides via Molybdenum-Catalyzed Hydrostannation. Org. Lett. 2013, 15, 6246-6249; e) Kerr, D. J.; Miletic, M.; Manchala, N.; White, J. M.; Flynn, B. L. Asymmetric Synthesis of (+)- and (-)-Pauciflorol F: Confirmation of Absolute Stereochemistry. Org. Lett. 2013, 15, 4118-4121; f) Manchala, N.; Law, H. Y. L.; Kerr, D. J.; Volpe, R.; Lepage, R. J.; White, J. M.; Krenske, E. H.; Flynn, B. L. Multistereocenter-Containing Cyclopentanoids from Ynamides via Oxazolidinone-Controlled Nazarov Cyclization. J. Org. Chem. 2017, 82, 6511-6527; g) Carlsen, P. N.; Stoutenburg, E. G.; Frontier, A. J. SYNTHESIS-SYNLETT Lecture: Toward the Asymmetric Synthesis of Tetrapetalone A: Prepara- tion of an Enantioenriched Indane Intermediate and Strategy for Endgame Glycosylation. Synthesis 2018, 50, 1238-1245; h) Mandla, K. A.; Moore, C. E.; Rheingold, A. L.; Figueroa, J. S. Regioselective Formation of (E)- $\beta$-Vinylstannanes with a Topologically Controlled Molybdenum-Based Alkyne Hydrostannation Catalyst. Angew. Chem. Int. Ed. 2018, 57, 6853-6857.

29. For a review, see: a) Zhou, B.; Tan, T.-D.; Zhu, X.Q.; Shang, M.; Ye, L.-W., Reversal of Regioselectivity in Ynamide Chemistry. ACS Catal. 2019, 63936406. For a recent example, see: b) Xu, Y.; Sun, Q.; Tan, T.-D.; Yang, M.-Y.; Yuan, P.; Wu, S.-Q.; Lu, X.; Hong, X.; Ye, L.-W., Organocatalytic Enantioselective Conia-Ene-Type Carbocyclization of Ynamide Cyclohexanones: Regiodivergent Synthesis of Morphans and Normorphans. Angew. Chem. Int. Ed. 2019, 58, 16252-16259.

30. a) Wagner, P.; Donnard, M.; Girard, N., LigandControlled Regiodivergent Hydroformylation of Ynamides: A Stereospecific and Regioselective Access to 2- and 3-Aminoacroleins. Org. Lett. 2019, 21, 8861-8866; b) Allegue, D.; González, J.; Fernández, S.; Santamaría, J.; Ballesteros, A., Regiodivergent Control in the Gold(I) Catalyzed Synthesis of 7Pyrazolylindoles from 1-Propargyl-1Hbenzotriazoles and Ynamides through $\alpha$-Imino Gold(I) Carbene Complexes. Adv. Synth. Catal. 2019, 361, 758-768.

31. AIBN is also an efficient radical initiator at elevated temperature (benzene, reflux). Under these conditions, ynamide $\mathbf{1 q}$ led to $\boldsymbol{\alpha}, \boldsymbol{Z}-\mathbf{5 q}(56 \%), \boldsymbol{\beta}, \boldsymbol{Z}-\mathbf{6 q}$ (28\%) and 3-(3-(4-methoxyphenyl)-1,1-diphenyl$1 H$-benzo[b]germol-2-yl)oxazolidin-2-one 10q $(8 \%)$, resulting from the addition of the intermediate vinyl radical onto one of the phenyl rings of the triphenylgermyl substituent, followed by aromatization. The structure of 10q was determined by extensive NMR investigations. See Supporting information for details.

32. Proof of structures for all four isomers $(\boldsymbol{\alpha}, \boldsymbol{E} ; \boldsymbol{\beta}, \boldsymbol{E}$; $\boldsymbol{\alpha}, \boldsymbol{Z} ; \boldsymbol{\beta}, \boldsymbol{Z})$ rely on extensive NMR experiments (1D and 2D) for compounds $\boldsymbol{\alpha}, \boldsymbol{E}-\mathbf{3 a}, \boldsymbol{\beta}, \boldsymbol{E}-\mathbf{4 a}, \boldsymbol{\alpha}, \boldsymbol{Z}-\mathbf{5 q}$, $\boldsymbol{\beta}, \boldsymbol{Z}-\mathbf{6 a}$ and $\boldsymbol{\beta}, \boldsymbol{Z}$-6q. In addition, $\mathrm{X}$-ray crystallographic data for $\boldsymbol{\alpha}, \boldsymbol{E}-\mathbf{3 r}$ (CCDC 1992925), $\boldsymbol{\beta}, \boldsymbol{E}-\mathbf{4 a}$ (CCDC 1992926) and $\boldsymbol{\alpha}, \boldsymbol{Z}-\mathbf{5 q}$ (CCDC 2000304) were obtained. See Supporting Information for details.

33. 2-(Diphenylphosphino)phenyl 2-(diphenyl- phosphinoyl)phenyl ether (DPEPhos-monoxide) has been previously characterized by X-ray diffraction studies, see: Tooke, D. M.; Wilting, J.; Vogt, D.; Spek, A. L., 2-(Diphenylphosphino)phenyl 2(diphenylphosphinoyl)phenyl ether. Acta Cryst. Section E 2005, 61, o2406-02407

34. tert-Butyl carbamates led to almost non-selective reactions. For example, under conditions A2, tert-butyl phenyl(phenylethynyl)carbamate led to an $\alpha / \beta$ ratio of 41:59 while under conditions B2, an $\alpha / \beta$ ratio of 21:79 was obtained. In addition, the products were not separable by silica gel chromatography.

35. While 3-carbomethoxyindole 1d led to good $\alpha$ selectivty under conditions A2 and B1, the corre- 
sponding methyl 1-(phenylethynyl)-1H-pyrrole-3carboxylate led to lower selectivities (A2: $\alpha / \beta=$ $69: 31, \mathrm{~B} 1: \alpha / \beta=47: 53)$ and the products were not separable by silica gel chromatography.

36. a) Amatore, C.; Jutand, A.; M'Barki, M. A., Evidence of the formation of zerovalent palladium from $\mathrm{Pd}(\mathrm{OAc})_{2}$ and triphenylphosphine. Organometallics 1992, 11, 3009-3013; b) Amatore, C.; Jutand, A.; Thuilliez, A., Formation of Palladium(0) Complexes from $\mathrm{Pd}(\mathrm{OAc})_{2}$ and a Bidentate Phosphine Ligand (dppp) and Their Reactivity in Oxidative Addition. Organometallics 2001, 20, 3241-3249.

37. Due to the rapid palladium-catalyzed dehydrogenative coupling of $\mathrm{Bu}_{3} \mathrm{SnH}$, leading to $\mathrm{Bu}_{6} \mathrm{Sn}_{2}, 1.5$ equivalent of $\mathrm{BuSnH}$ is required in this hydrostannylation reaction. See Supporting Information for experimental details.

38. Jover, J.; Cirera, J., Computational assessment on the Tolman cone angles for P-ligands. Dalton Trans. 2019, 48, 15036-15048.

39. In, J.; Hwang, S.; Kim, C.; Seo, J. H.; Kim, S., Synthesis of 3,4-Dihydroisoquinolin-1-ones from $\mathrm{N}$ Boc-( $\beta$-Arylethyl)carbamates via Isocyanate Intermediates. Eur. J. Org. Chem. 2013, 965-971. 
Table of Contents artwork

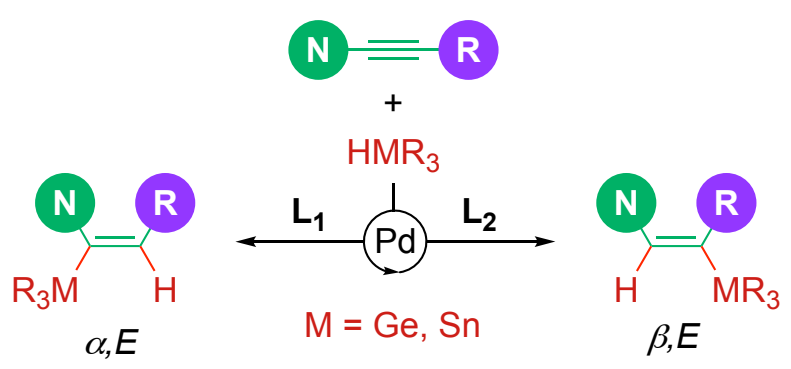

